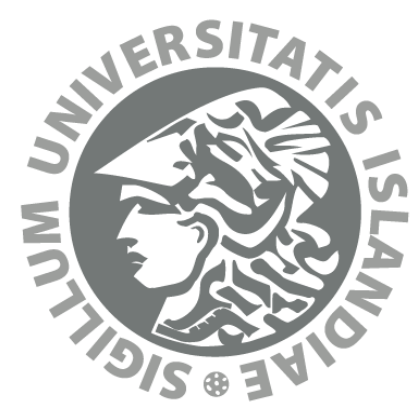

\title{
Towards a Decision Support Framework for Technologies used in Cold Supply Chain Traceability
}

\author{
Kristín Óskarsdóttir
}

Faculty of Industrial Engineering, Mechanical

Engineering and Computer Science

University of Iceland

2017 



\title{
Towards a Decision Support Framework for Technologies used in Cold Supply Chain Traceability
}

\author{
Kristín Óskarsdóttir
}

30 ECTS thesis submitted in partial fulfillment of a Magister Scientiarum degree in Industrial Engineering

Advisor(s)

Guðmundur Valur Oddsson

Sæmundur E. Porsteinsson

Master's Examiner

Ari Jónasson

Faculty of Industrial Engineering, Mechanical Engineering and Computer Science

School of Engineering and Natural Sciences

University of Iceland

Reykjavik, May 2017 
Towards a Decision Support Framework for Technologies used in Cold Supply Chain Traceability

30 ECTS thesis submitted in partial fulfillment of a Magister Scientiarum degree in Industrial Engineering

Copyright (C) 2017 Kristín Óskarsdóttir

All rights reserved

Faculty of Industrial Engineering, Mechanical Engineering and Computer Science

School of Engineering and Natural Sciences

University of Iceland

Hjarðarhaga 2-6

107, Reykjavik

Iceland

Telephone: 5254000

Bibliographic information:

Kristín Óskarsdóttir, 2017, Towards a Decision Support Framework for Technologies used in Cold Supply Chain Traceability, Master's thesis, Faculty of Industrial Engineering, Mechanical Engineering and Computer Science, University of Iceland, pp. 62.

Printing: Háskólaprent

Reykjavik, Iceland, May 2017 


\section{Abstract}

In recent years, a need for product traceability in the cold supply chain has emerged. The purpose of this study was to identify and map out different kinds of identification technologies and techniques used for cold supply chain traceability. This was done by looking into what traceability solutions are available right now through literature review. The results from this review were then further analyzed to obtain a basis for the current state of knowledge, technical solutions and to identify possible traceability structures in the cold chain. A decision support framework was constructed for choosing a suitable technical solution. It consists of a table listing different functions and attributes of technologies and a decision-tree. The decision support framework created from this work will help the user to identify what kind of traceability technology and structure best suits his products. This is important, as it can often be difficult for the user to decide which technology is most beneficial for his company. That is why this decision support framework will enable him to decide what is technologically feasible, practical, economical, can sustain reputation, quality and safety of the products.

\section{Útdráttur}

Á undanförnum árum hefur aukin pörf myndast fyrir pví að rekja vörur í köldum aðfangakeðjum. Tilgangur pessarar rannsóknar var að greina og kortleggja mismunandi tegundir af auðkenningartækni og aðferðir sem notaðar eru fyrir rekjanleika í köldum aðfangakeðjum. Petta var gert með pví að skoða hvaða rekjanleika lausnir eru tiltækar með fræðilegri leit. Niðurstöðurnar úr pessari leit voru greindar enn frekar til pess að mynda grunn fyrir núverandi pekkingarstig, tæknilegar lausnir og til pess að greina hugsanlegar tengingar meðal kaldra aðfangakeðja. Ákvörðunarstuðningskerfi var búið til með pað fyrir augum að velja viðeigandi tæknilega lausn. Kerfi petta samanstendur af töflu sem sýnir mismunandi tæknilega virkni og eins ákvörðunartré. Kerfið sem var gerður út frá pessari vinnu mun hjálpa peim sem notfæra sér tæknina, p.e. notendum. Pannig geta notendur séð hverskonar tækni og uppbygging er hagstæð fyrir vörur peirra er verðar rekjanleika. Petta er mikilvægt par sem oft er erfitt fyrir notendur að ákvarða hvaða tækni hentar beirra fyrirtæki best. Pannig mun petta ákvörðunarstuðningskerfi gera notendum kleift að ákveða hvað er tæknilega raunhæft, hagnýtt, hagkvæmt, getur viðhaldið góðu orðspori, gæðum og öryggi varanna. 



\section{Table of Contents}

List of Figures ............................................................................................................................ vii

List of Tables............................................................................................................................... ix

Abbreviations .......................................................................................................................................... $\mathrm{x}$

Acknowledgements .................................................................................................................................... xi

1 Introduction.................................................................................................................... 1

2 Methodology ............................................................................................................. 3

2.1 Defining the research question ....................................................................... 3

2.2 Instrument development and site selection ....................................................... 5

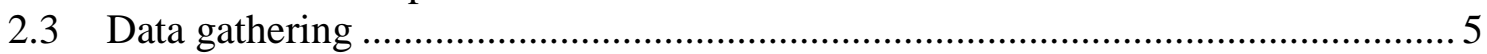

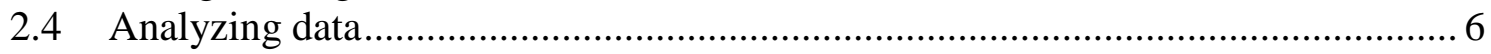

2.5 Disseminating the research findings............................................................... 7

3 Theoretical Background ......................................................................................9

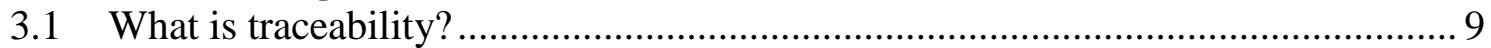

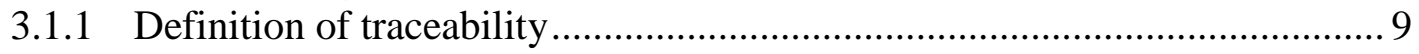

3.1.2 Types of traceability ............................................................................ 10

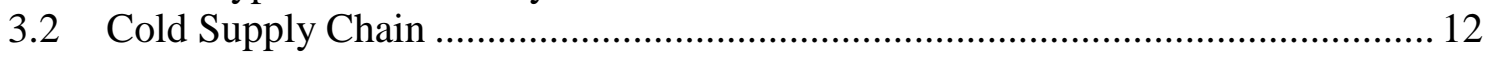

3.2.1 Supply Chain Management and Logistic Management ............................... 12

3.2.2 Cold Chain ............................................................................................. 12

3.3 Importance of traceability in food supply chains ................................................... 13

3.3.1 Driving forces for implementing …………………................................ 13

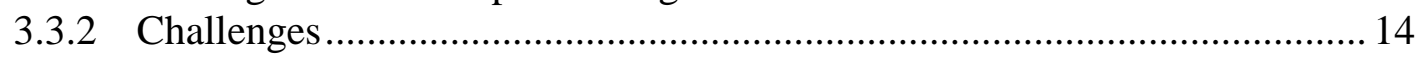

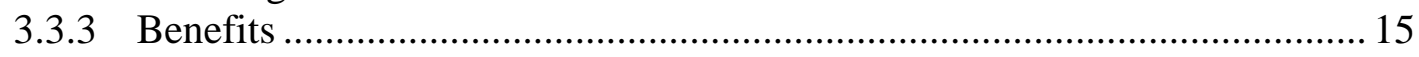

3.4 Legislations for food traceability …………………………………………..... 17

3.4.1 European legislation.............................................................................. 17

3.4.2 United States of America legislation ........................................................ 18

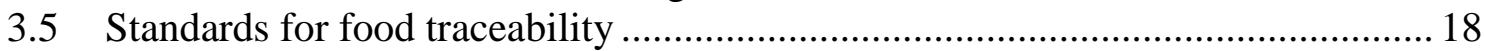

3.5.1 International traceability standards .......................................................... 18

4 Identification technologies used in traceability ............................................................... 21

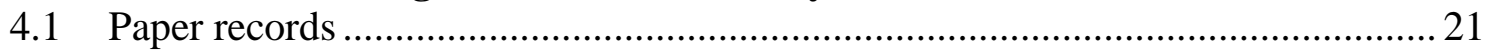

4.2 Alphanumerical codes ................................................................................. 21

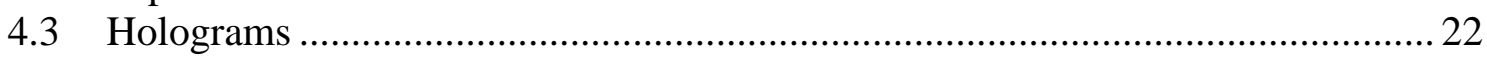

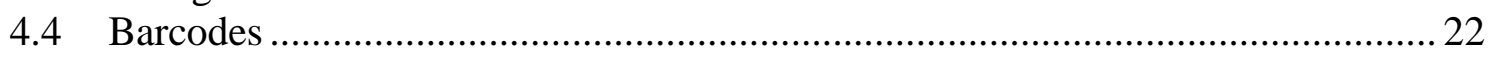

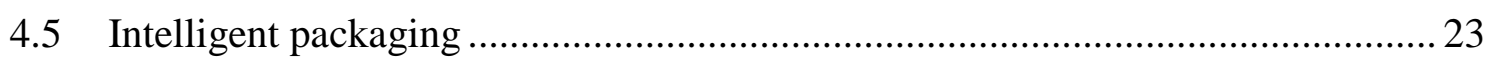

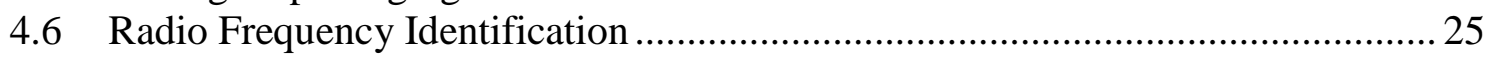

$4.7 \quad$ Wireless Sensor Networks........................................................................... 28

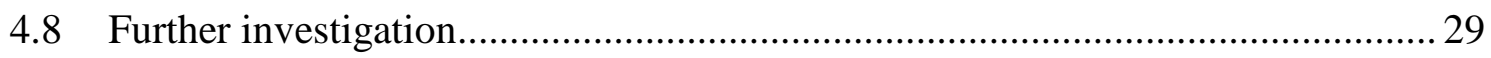

5 Analysis of Traceability Structures in Cold Chains ……………….................................31 


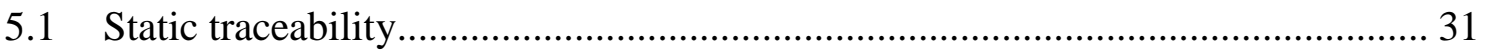

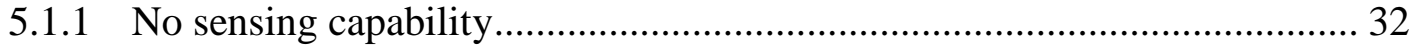

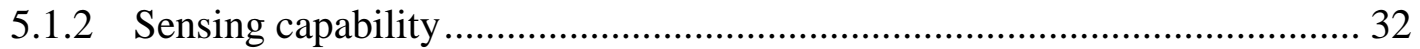

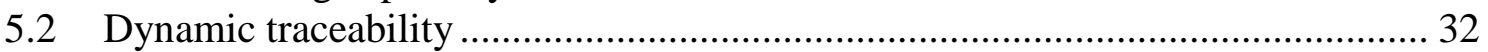

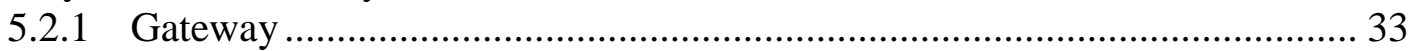

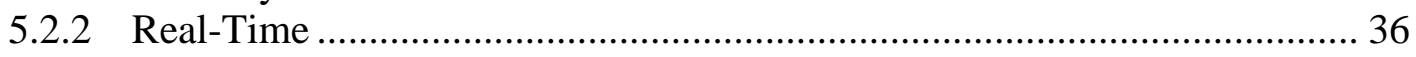

6 Construction of the Decision Support Framework .................................................... 39

7 Field Trip....................................................................................................................................... 47

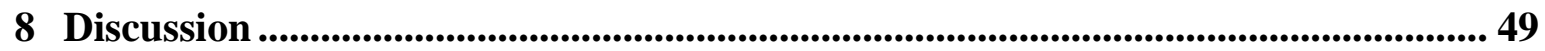

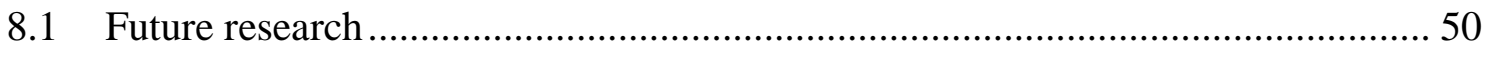

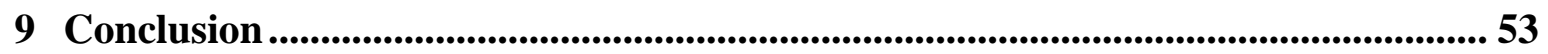

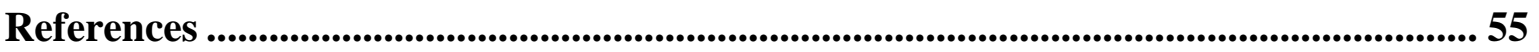

Appendix ................................................................................................................................................. 61 


\section{List of Figures}

Figure 2.1 The five stage reasearch process model as illustrated by Stuart et al. (2002).

Figure 2.2 The theory-building process adapted from Handfield and Melnyk (1998).......... 4

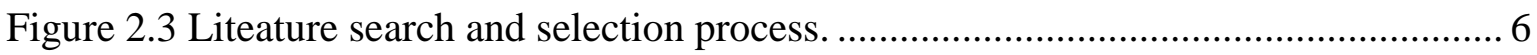

Figure 2.4 Structure of a mind map made with MindManager by Mindjet.......................... 6

Figure 3.1 Material and information flow for the case of a food supply chain (Bosona \& Gebresenbet, 2013)............................................................................... 10

Figure 3.2 Conceptual framework of a food traceability system (Aung \& Chang, 2014).

Figure 3.3 Drivers for traceability (Aung \& Chang, 2014) ............................................. 13

Figure 3.4 The "one-step-forward-one-step-back" approach .......................................... 18

Figure 4.1 Example of different holograms (NovaVision, 2017).................................. 22

Figure 4.2 An Indian GS1 barcode identifiable by the 890 digits (Dandage et al., 2017).

Figure 4.3 QR (Quick Response) code (Denso ADC, 2011). 23

Figure 4.4 Illustration of environmental and quality indicators in IP (Heising et al., 2014).

Figure 4.5 Examples of indicators: (a) TTI (b) Freshness indicator (Mohebi \& Marquez, 2015).

Figure 4.6 Different categories of RFID tags (a) passive, (b) active and (c) semipassive adopted from Khan et al. (2009)................................................... 26

Figure 4.7 Conceptual framework of a Wireless Sensor Network (Wang et al., 2015)..... 29

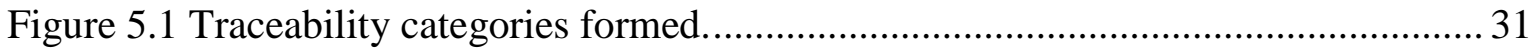

Figure 5.2 Logistical process for fresh fish (Trebar et al., 2013).................................... 34

Figure 5.3 A central information service proposed by Kelepouris et al. (2007)................ 34

Figure 5.4 Traceability guidance table showing CTEs and key data elements adapted from Hickey and Bhatt (2013).................................................................. 36

Figure 5.5 A WSN architecture adapted from Xiao et al. (2016)...................................... 38 
Figure 6.1 Illustration of the whole decision-tree for a cold chain traceability application.

Figure 6.2 Decision-tree for a cold chain traceability application, choosing a suitable traceability technology system.

Figure 6.3 Final selection process when using paper records, alphanumerical codes and/or holograms.

Figure 6.4 Final selection process when using barcodes. .............................................. 44

Figure 6.5 Final selection process when using intelligent packaging with TTI................ 45

Figure 6.6 Final selection process when using passive RFIDs. ................................... 45

Figure 6.7 Final selection process when using active or semi-passive RFIDs. ................ 46

Figure 6.8 Final selection process when using a WSN system.................................... 46

Figure 7.1 Printable electronic tags an illustration of fractions and surface roughness due to the material of the printed surface. 


\section{List of Tables}

Table 2.1 Research strategy with theory-building activities adapted from Handfield and Melnyk (1998) and Stuart et al. (2002)................................................... 4

Table 3.1 Possible challanges when implementing a tracebility system........................... 15

Table 3.2 Possible benefits when implementing a traceability system. ............................ 16

Table 4.1 Classification of RFID tags based on frequency adopted from Ruiz-Garcia

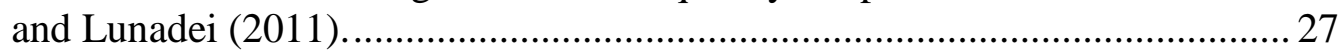

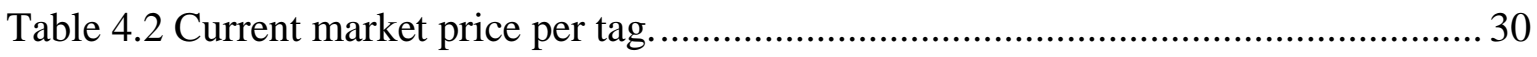

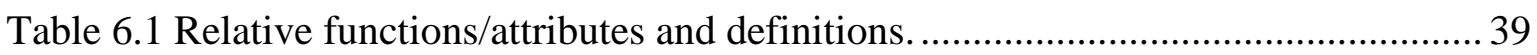

Table 6.2 Traceability functions/attributes and technologies overview............................ 40

Table 7.1 Demonstration of answers gathered at Oulu University of Applied Science, adopted from Appendix ................................................................................. 48

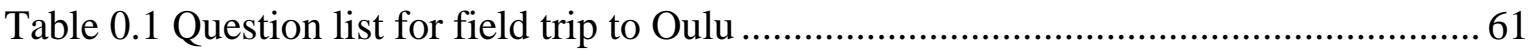




\section{Abbreviations}

CAC: Codex Alimentarius Commission

CSCMP: Council of Supply Chain

Management Professionals

CTE: Critical Tracking Event

EAN: European Article Numbering

EPC: Electronic Product Code

EPCIS: Electronic Product Code

Information Service

FAO: Food and Agriculture Organization of the United Nations

FDA: Food and Drug Administration

FSMA: Food Safety Modernization Act

GPRS: General Packet Radio Service

GPS: Global Positioning System

GS1: Global Standardization

Organization 1

HACCP: Hazard Analysis Critical

Control Point

HF: High Frequency

IP: Intelligent Packaging

ISM: Industrial, Scientific and Medical

ISO: International Standardization

Organization

LF: Low Frequency

NA: Not Applicable

QR code: Quick Response code

RFID: Radio Frequency Identification

SC: Supply Chain
SCM: Supply Chain Management

TTI: Time Temperature Indicator

USA: United Stated of America

UCC: Uniform Code Council

UHF: Ultra High Frequency

WHO: World Health Organization

WSN: Wireless Sensor Network

Avg. = Average

I.e. $=$ That is

E.g. $=$ For Example

Temp. $=$ Temperature 


\section{Acknowledgements}

Firstly, I would like to thank my family and friends for their support and encouragement during the writing of this thesis. Special thanks to my mother, Helga Gunnlaugsdóttir, for reading through this thesis with me, it provided me with constructive commentaries and useful insights.

Secondly, I would like to acknowledge my advisors Guðmundur Valur Oddsson and Sæmundur E. Porsteinsson at the University of Iceland, who helped me define and develop this thesis. Especially Guðmundur who always had his door open whenever I had questions and steered me in the right direction.

Finally, I would like to thank Smart-Fish for the financial support that enabled me to visit Oulu University of Applied Science. I would also like to thank the hardworking scientists who took time out of their work to educate me on their research. 



\section{Introduction}

In recent years, an interest in product traceability in the food supply chain (SC) has emerged (Aung \& Chang, 2014; Olsen \& Borit, 2013). Even though the interest has become more prominent recently it can be traced back 5000 years to the Egyptian society where consumers of wine were informed about the provenance of the vineyard and the year of production with writing put on the amphora (Lavelli, 2013). Likewise, animal identification can also be dated back 3800 years where markings where put on their bodies (Bosona \& Gebresenbet, 2013).

Most recently, incidents and scandals in the food industry such as outbreaks of foodborne illnesses, e.g. salmonella and E. coli, call for increased safety guarantees and transparency in the food SC. Further, it is of importance to develop laws, policies and standards regarding food safety and quality management to respond to the issues at hand (Aung \& Chang, 2014). In order to ensure consumers' health and to protect the reputation of companies as massive recalls can lead to direct and indirect costs (Bosona \& Gebresenbet, 2013; H. Ringsberg, 2014) causing wide ranged media attention around the world (Olsen \& Borit, 2013). Many may e.g. still remember the horsemeat scandal in 2013 where major European retailers had to recall minced meat products. For TESCO alone the international sales dropped by 4.6 per cent equaling \$408 million in lost shares due to this scandal (The Associated Press, 2013).

Due to globalization of food supply the food chain integrity not only includes safety concerns but also issues related to place of origin, fraud and quality concerns (Aung \& Chang, 2014; Dandage et al., 2017). There is a need for a whole chain traceability system that gives information on origin, processing, retailing and destinations from farm to end-user. This is a shared responsibility of all actors in the food chain including governments, industries and consumers (Aung \& Chang, 2014). As technology and standards improve, the potentials and benefits of installing food traceability systems have increased making it an important tool (Olsen \& Borit, 2013).

This study is part of the Northern Periphery and Arctic Programme Smart-Fish that has the aim of developing a Smart-Label System, which will be able to monitor temperature and track perishable goods during transportation using Global Positioning System (GPS). The data will be sent to an online server where users can monitor their products during transportation to verify proper handling that ensures product quality and shelf life. The aim of this study is to investigate the current situation in a cold food supply chain and map out technologies and techniques available. A decision support framework will be developed. The framework will help supply chain actors to choose appropriate tracking solutions for their products. As Peter Drucker said "What gets measured gets improved" (Shore, 2014). 
To help get an overview of the current situation and estimating the need for various SCs this study will seek to answer two questions:

1. What kind of traceability solutions are available right now in the cold supply chain?

2. Is it possible to develop a decision support framework for choosing a suitable traceability solution?

This thesis consists of nine chapters including introduction, conclusion and future research. The second chapter discusses the methodology used during the process of writing. The third chapter gives a theoretical background into traceability in supply chains while the forth chapter shows which kind of traceability technologies are currently available. The fifth chapter contains an analysis of the gathered information. The sixth chapter shows the construction of a decision support framework. While, the seventh chapter is a summary from a field trip followed by a discussion and future research in chapter eight. Finally, in chapter nine the conclusions from this thesis are drawn. 


\section{Methodology}

The focus of this thesis was to investigate the cold supply chain with a focus on perishable food products and explore different kinds of technologies and techniques utilized. The cold chain can include other types of perishable products such as medicine and pharmaceuticals, literature falling into these categories were therefore excluded.

In order to approach the subject and answer the research questions that have been put forward in a structured way the case research process by Stuart et al. (2002) and the theory-building process by Handfield and Melnyk (1998) have been used. In a way these two processes have similar attributes but in the mind of the author the case research process by Stuart et al. (2002) gives the subject matter a better structure and understanding. The methodology used here will therefore be based on Stuart et al. (2002) with the implementation of Handfield and Melnyk (1998) when appropriate. It should also be pointed out that Robert B. Handfield is a mutual author of these two publications so similar attributes are to be expected.

According to Stuart et al. (2002) the research process has five stages; (1) Defining the research question, (2) Instrument development and site selection, (3) Data gathering, (4) Analyzing data and (5) Disseminating the research findings. The five stages according to Stuart et al. (2002) are illustrated in Figure 2.1. In the following chapters, each step will be addressed.

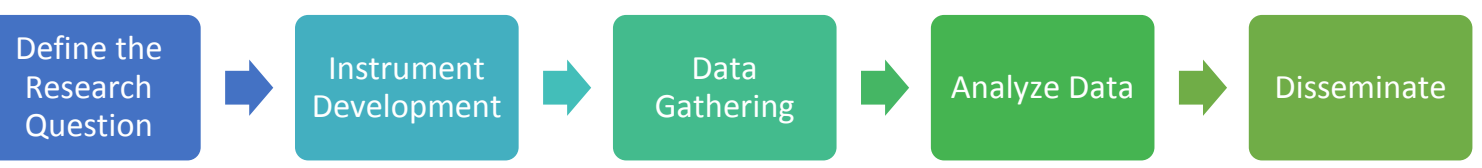

Figure 2.1 The five stage reasearch process model as illustrated by Stuart et al. (2002).

\subsection{Defining the research question}

The first stage in Stuart et al. (2002) research process model involves defining the research question. This involves building up a body of knowledge and gathering theory. Handfield and Melnyk (1998) described the theory-building process, see Figure 2.2, and summarized different types of techniques used for each theory-building process; (1a) Discovery, (1b) Description, (2) Mapping, (3) Relationship Building, (4a-b) Theory Validation and (5) Theory Extension/Refinement.

Table 2.1 is adapted from a larger table from both Stuart et al. (2002) and Handfield and Melnyk (1998), it illustrates the connection between research purpose and question. The steps description, mapping and relationship building (Table 2.1) of the theory-building process by Handfield and Melnyk (1998) fits the work done in this thesis. 


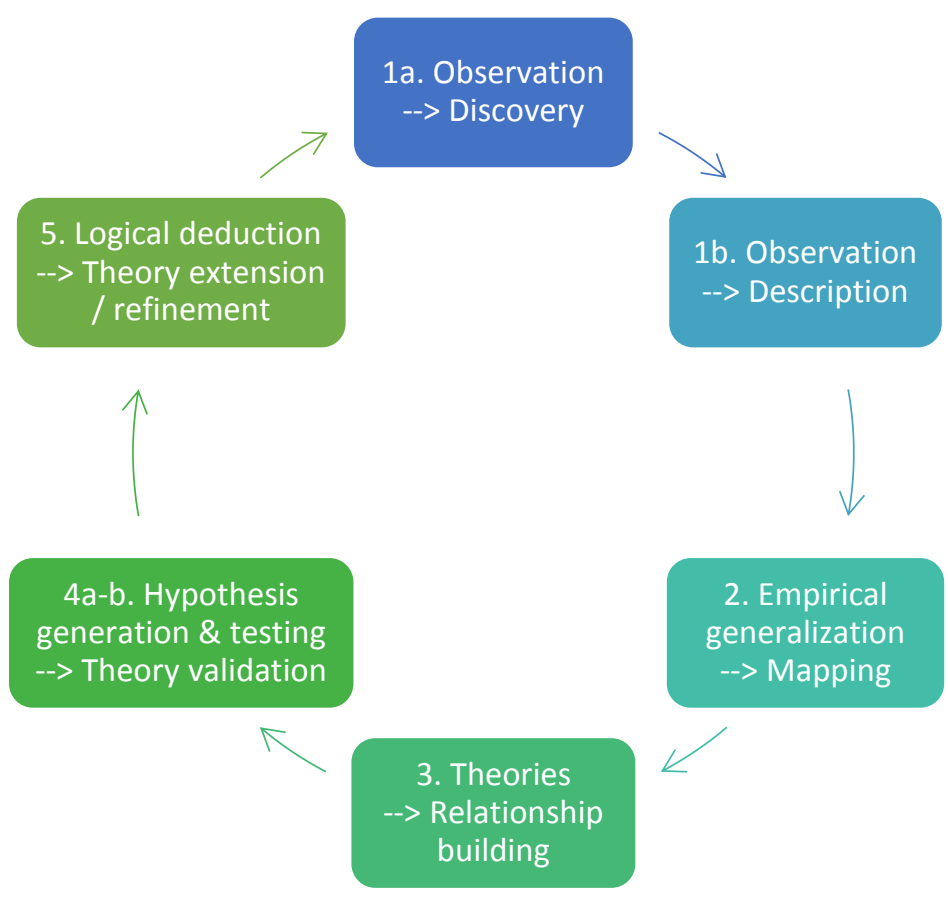

Figure 2.2 The theory-building process adapted from Handfield and Melnyk (1998).

Table 2.1 Research strategy with theory-building activities adapted from Handfield and Melnyk (1998) and Stuart et al. (2002).

\begin{tabular}{|c|c|}
\hline Purpose & Typical research question \\
\hline 1b. Description & What is there? \\
\hline \multirow[t]{2}{*}{ Explore territory } & What are the key issues? \\
\hline & What is happening? \\
\hline 2. Mapping & What are the key variables? \\
\hline $\begin{array}{l}\text { Identify and describe key } \\
\text { variables }\end{array}$ & What are the key themes, patterns or categories? \\
\hline 3. Relationship building & What are the patterns or linkages between variables? \\
\hline Identify linkages between & Can an order in the relationship be identified? \\
\hline variables, & Why do these relationships exist? \\
\hline causal understanding & \\
\hline
\end{tabular}

The proposed research questions can be positioned in the theory-building step presented in Table 2.1 as follows:

- What kind of traceability solutions are available right now in the cold supply chain?

$\circ \quad$ Step 1b. Description and 2. Mapping

- Is it possible to develop a decision support framework for choosing a suitable traceability solution?

○ Step 3. Relationship building 


\subsection{Instrument development and site selection}

The second step in Stuart et al. (2002) research process model is the development of a research instrument and selection of the appropriate field sites. As the research question has been defined, measurement instruments should be developed to capture data for future analysis. This provides the researchers with the necessary focus to help them stay on target and to keep information gathering as efficient as possible (Stuart et al., 2002).

In this study most of the information gathered is based on literature review. Literature searches were carried out using The Web of Science ${ }^{\mathrm{TM}}$ database in order to gather data about previous studies. In addition, the researcher visited the Oulu University of Applied Sciences in Finland which is a collaborative partner in the Smart-Fish project. The purpose of this visit was to get an overview of current technologies used in the field by using observations and a question list.

\subsection{Data gathering}

The third step in Stuart et al. (2002) research process model is data gathering. It is important to use reliable information and gather it from trusted sources. Web of Science ${ }^{\mathrm{TM}}$ is considered a trusted source as all articles submitted must go through evaluation. The search was carried out in February 2017 using the Web of Science ${ }^{\mathrm{TM}}$ and the search terms and selection process used can be seen in Figure 2.3.

The initial search terms included "track*", "monitor*", "trace*”, "perishabl*", "fish*", "medicin", "pharma*”, "food", "supply", "cold", "chill*”, "chain" and "transport*” which resulted in 5303 articles. This was clearly a too broad search and therefore the decision was made to exclude "medicin", "pharma*", "chill*" and "transport*" in hope of narrowing down the search and focus more on the cold food supply chain. The search consisted of terms indicating traceability such as "track", "monitor*" and "trace*" which were narrowed down using terms indicating the types of products, "perishabl*", "fish*" and "food", in a "supply" or "cold" "chain".

The data used in this thesis is mainly based on the final selection of the 43 articles and occasionally information from websites that were considered a trusted source were included to complement data that was not available in the scientific articles. 


\begin{tabular}{|c|c|}
\hline $\begin{array}{l}\text { Initial } \\
\text { search }\end{array}$ & $\begin{array}{l}\text { - Site: Web of Science }{ }^{\mathrm{TM}} \text { Core Collection } \\
\text { - Timespan: All years } \\
\text { - Search: TS }=((\text { track* OR monitor* OR trace*) NEAR/2 (perishabl* OR fish* OR food) } \\
\text { AND ((supply OR cold) NEAR/2 chain) }) \\
\text { - Result: } 136\end{array}$ \\
\hline $\begin{array}{l}\text { First } \\
\text { analysis }\end{array}$ & $\begin{array}{l}\text { - Articles regarding cold food supply chain both theoretical and technical } \\
\text { - Excluding: Backward traceability, recall studies, outbreaks, microbiology, diseases, } \\
\text { chemistry, market structure, viruses, pathogens, pesticides, infections, risk management } \\
\text { \& climate change } \\
\text { - Result: } \mathbf{5 7}\end{array}$ \\
\hline $\begin{array}{l}\text { Final } \\
\text { selectic }\end{array}$ & $\begin{array}{l}\text { - Articles selected from the initial search } \\
\text { - Result: } \mathbf{4 3}\end{array}$ \\
\hline
\end{tabular}

Figure 2.3 Liteature search and selection process.

\subsection{Analyzing data}

The fourth step in Stuart et al. (2002) research process model is analyzing the data found in the previous step. The problem of analyzing the data is determining what has been learned and how to present it. This can take much time and effort. Three weaknesses in data analysis have been identified as the inability to extract significant patterns, the inability to simplify from descriptive information and the inability to think laterally. A useful technique to see order from chaos involves structuring the data in a variety of patterns (Stuart et al., 2002).

With the use of the MindManager software from Mindjet several mind maps were structured during the reading of the literature. The mind maps were structured around an identified central topic, its main topics and subtopics, see Figure 2.4. This gave the researcher a good structure to sort the gathered information in an organized way in order to identify patterns and possible connection between traceability structures.

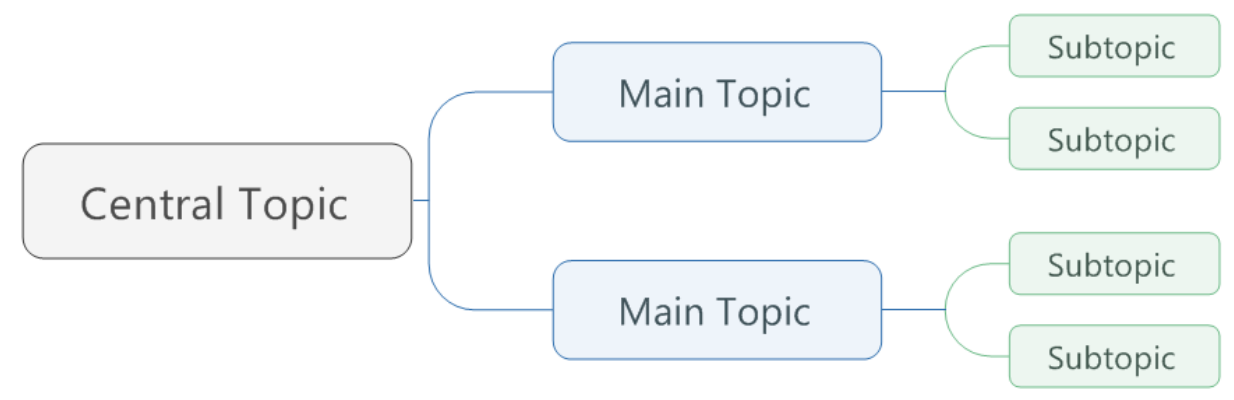

Figure 2.4 Structure of a mind map made with MindManager by Mindjet. 


\subsection{Disseminating the research findings}

The fifth step in Stuart et al. (2002) research process model is disseminating the research findings with publication. This step is obtained here by presenting the findings in this thesis. The findings will answer the research questions that were presented at the beginning. The findings will also lead to discussions and conclusions, identification of constrains and future research. 



\section{Theoretical Background}

In this chapter, a wide range of theoretical background connected with traceability in the food SC will be discussed. As mentioned in the previous chapter the research is based on articles gathered from The Web of Science ${ }^{\mathrm{TM}}$ database, referenced articles of interest were read and if needed, data from trusted online sources were used.

After a deep analysis of the collected literature, the author decided to divide the theoretical background into five subchapters. These five subchapters give the reader an overview of (1) what traceability is, (2) how supply chain management is defined and what a cold chain is, (3) the importance of traceability with its benefits and challenges, (4) what legislations are available and (5) standards for food traceability. This is done to provide the reader with the knowledge of how complex a supply chain can be and why identification traceability technologies can be useful tools for perishable products.

\subsection{What is traceability?}

\subsubsection{Definition of traceability}

There are a vast amount of conflicting definitions of what the term "traceability" means as the definitions can be very broad or strict (Bosona \& Gebresenbet, 2013; Olsen \& Borit, 2013). The two key terms in traceability literatures are tracking and tracing, Bosona and Gebresenbet (2013) noticed that there was a lack of consistency in using these two key terms, which is a basis for confusion when used interchangeably.

Tracking is defined as "The ability to follow the movement of food through specified stages of production, processing and distribution" i.e. the downstream direction or forward process where the end users and trading partners are identified by location in the supply chain (SC), see Figure 3.1 (Bosona \& Gebresenbet, 2013; Dandage et al., 2017; Storoy et al., 2013). Whereas tracing is defined as "The ability to trace the history, application or location of an entity by means of recorded identifications" i.e. the upstream direction or backward process where the origin is identified by history or records in the SC, see Figure 3.1 (Bosona \& Gebresenbet, 2013; Dandage et al., 2017; Storoy et al., 2013). Storoy et al. (2013) say that a good traceability system should have the capability of performing both functions efficiently. Since the effectiveness for one type can't imply the effectiveness for the other (Kelepouris et al., 2007).

Olsen and Borit (2013) took on the role of seeking out the different definitions of traceability and proposed a new definition based on the existing ones. They redefined traceability as "The ability to access any or all information relating to that which is under consideration, throughout its entire life cycle, by means of recorded identification". 


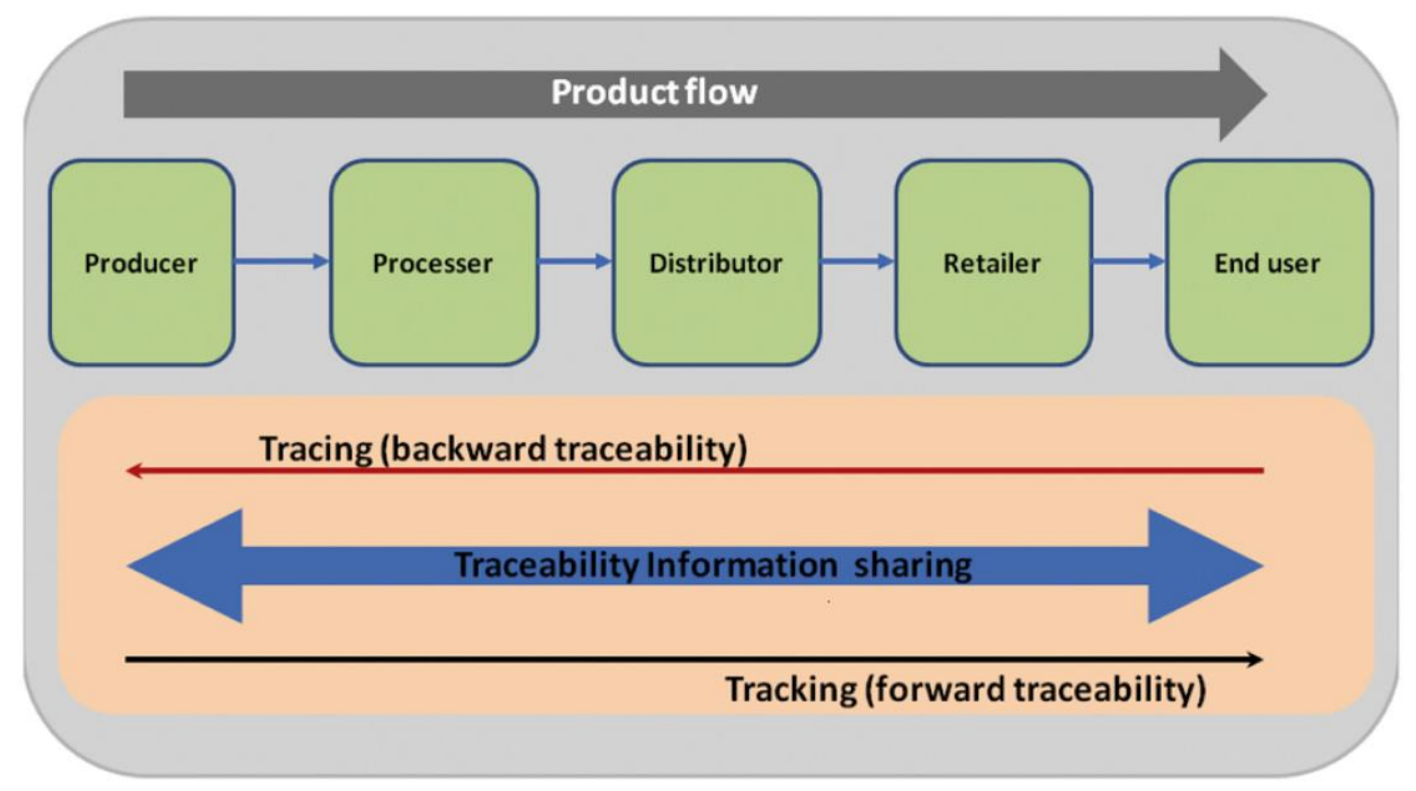

Figure 3.1 Material and information flow for the case of a food supply chain (Bosona \& Gebresenbet, 2013).

\subsubsection{Types of traceability}

Management of food traceability systems can be divided into two types, internal and external traceability.

\section{Internal traceability}

H. Ringsberg (2014) defined internal traceability as "the ability to track and trace unique products, components or units in internal processes within a company". Internal traceability links the identities of the raw material to the new Unique Product Identifier of the finished product at one-step of the SC. This is done to keep track of all the transitions, to see if materials have been processed, reconfigured or repacked internally to maintain the original identities (Aung \& Chang, 2014; Mgonja et al., 2013; Pizzuti \& Mirabelli, 2015; Zhang \& Bhatt, 2014).

Food safety requirements require every actor in a food SC to have internal record keeping system that supports the unique identification of product components and units $(\mathrm{H}$. Ringsberg, 2014). Internal traceability can also be called local traceability (H. A. Ringsberg \& Mirzabeiki, 2014).

\section{External traceability}

To achieve external food traceability internal food traceability is a prerequisite (Aung \& Chang, 2014; Mgonja et al., 2013; H. Ringsberg, 2014). H. Ringsberg (2014) defined external traceability as "the ability to track and trace unique products, components or units in the information flow linked to the physical movements of goods between companies or countries".

The main goal of external traceability is to guarantee the connection between the actors in the SC and to ensure the link between purchased products and their supplier, and the link between sold products and their clients (Pizzuti \& Mirabelli, 2015). It describes what and 
how data are transmitted and received. However, it also refers to the ability to track a products history between actors in the SC (Aung \& Chang, 2014; Mgonja et al., 2013).

To maintain external traceability all the unique identification numbers must be shared between the whole distribution channel participants, e.g. on product labels and related paper or electronic business documents. This links the physical products with the information requirements necessary for traceability (Zhang \& Bhatt, 2014).

Standards and methods for data interchange are crucial in external traceability as information is shared among different stakeholders (Dabbene et al., 2014). Companies can gain a competitive edge if they coordinate their logistic processes and share information since a SC is only as strong as its weakest link (H. Ringsberg, 2014). External traceability can also be called chain traceability (Mgonja et al., 2013; H. Ringsberg, 2014).

\section{Internal and external traceability}

If all SC actors have internal and external traceability, a whole SC traceability is achieved (Bhatt et al., 2013; Bosona \& Gebresenbet, 2013; Zhang \& Bhatt, 2014). Each traceability actor must be able to identify the direct source and recipient of traceable products. This is called the "one-step-forward-one-step-back" principle that ensures that essential information must be collected, recorded and shared. It is therefore not necessary that every actor in the SC knows the whole chain (Zhang \& Bhatt, 2014). See Figure 3.2 where internal and external traceability is demonstrated in a conceptual framework of a food tracebility stystem.

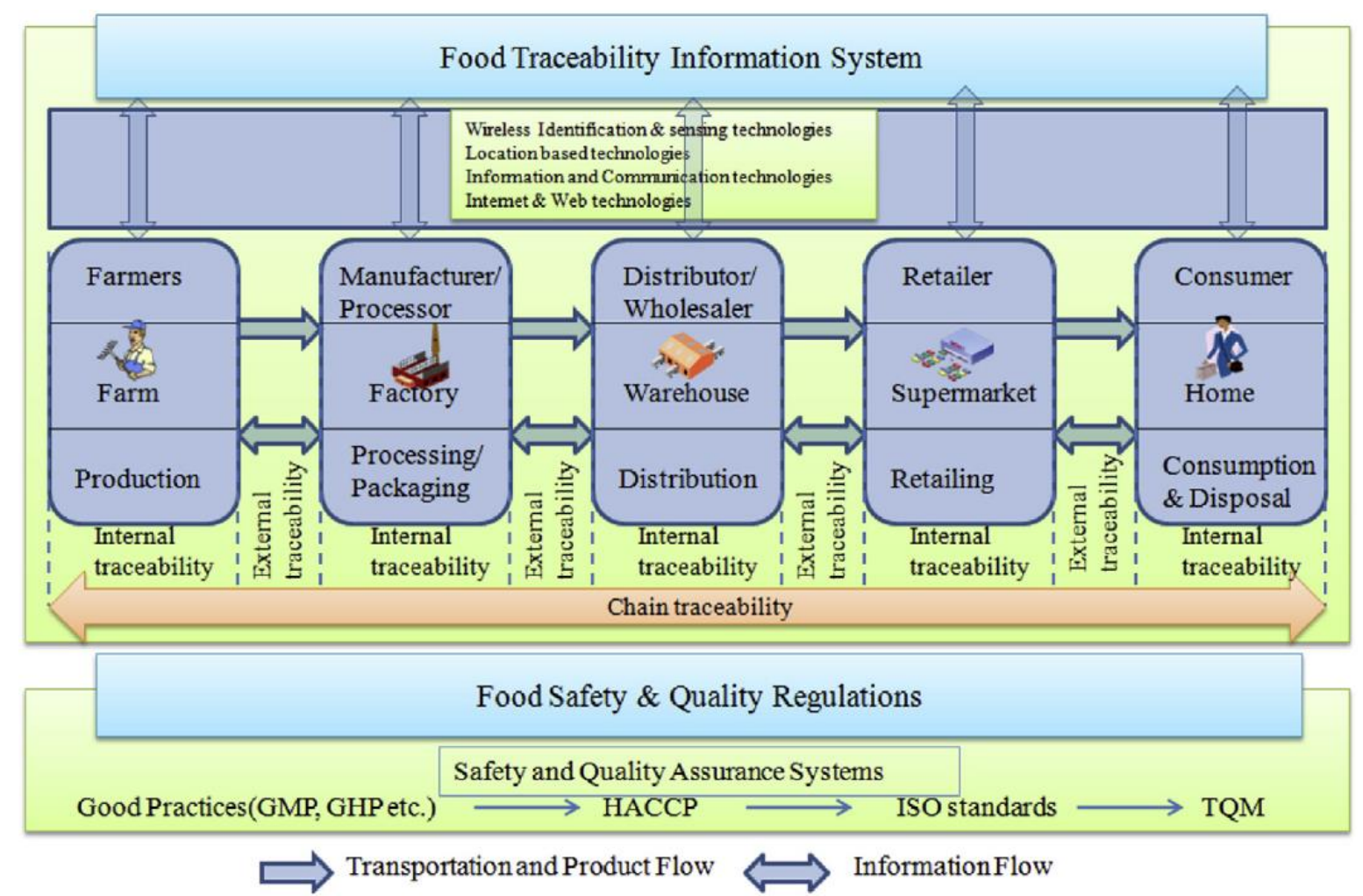

Figure 3.2 Conceptual framework of a food traceability system (Aung \& Chang, 2014). 


\subsection{Cold Supply Chain}

\subsubsection{Supply Chain Management and Logistic Management}

Supply Chain Management (SCM) as defined by the Council of Supply Chain Management Professionals (CSCMP, 2013): "Supply chain management encompasses the planning and management of all activities involved in sourcing and procurement, conversion, and all logistics management activities. Importantly, it also includes coordination and collaboration with channel partners, which can be suppliers, intermediaries, third party service providers, and customers. In essence, supply chain management integrates supply and demand management within and across companies.".

Bosona and Gebresenbet (2013) say that any information flow along the physical movement of products should be addressed within logistics management. The definition of logistics management is: "Logistics management is that part of supply chain management that plans, implements, and controls the efficient, effective forward and reverses flow and storage of goods, services and related information between the point of origin and the point of consumption in order to meet customers' requirements.” (CSCMP, 2013).

\subsubsection{Cold Chain}

The cold chain is defined as "the transportation of temperature sensitive products along a supply chain through thermal and refrigerated packaging methods and the logistical planning to protect the integrity of these shipments". Preparation, storage, transportation and monitoring must be performed from the suppliers to the receiving places for these temperature sensitive products (Luo et al., 2016). Perishable food products consist of vegetables, fruits, meats and fish (Kumari et al., 2015; Ruiz-Garcia et al., 2009). Other kinds of perishable products include flowers, pharmaceuticals and chemicals (Luo et al., 2016).

To be able to prolong the shelf life of perishable products the temperature is the most important factor (Kumari et al., 2015; Ruiz-Garcia et al., 2009) to ensure that perishable food products do not become damaged or compromised throughout their shipping process (Aung \& Chang, 2014; Luo et al., 2016). The SCM of fresh foods requires fast decisions since products are forwarded within hours after arrival at the distribution center, requiring accurate information for planning. Quality problems need to be detected as soon as possible and alarms triggered if temperature crosses thresholds (Ruiz-Garcia et al., 2009). Badia-Melis et al. (2016) mention that current cold chain monitoring systems are lacking the ability to provide real-time and accurate information regarding the products, which result in inaccurate data.

The food industry in developing countries is currently relying more on the cold chain, e.g. around 70 percent of all the food consumed in the USA is handled in cold chains. In comparison, less than 25 percent of the meat and about 5 percent of fruits and vegetable consumed in China are handled in cold chains. This is because China, like other developing countries, are facing challenges such as lack of temperature standards, out-of-date technologies, lack of skilled professionals and poor infrastructure (Luo et al., 2016). 


\subsection{Importance of traceability in food supply chains}

There are numerous driving forces for implementing a traceability system as well as challenges and benefits of implementation are described in the sections below.

\subsubsection{Driving forces for implementing}

The driving forces for implementing traceability are often a combination of two or more factors that influence the development and implementation of a food traceability system (Bosona \& Gebresenbet, 2013).

Possible driving forces for implementing traceability in the entire SC can be to maintain market power, strengthen reputation, minimize recalls, protect the trademark, improving SCM efficiency, gain competitive advantages and better market access, ensure consumer confidence, meet customer requirements, meet food quality targets, reduce risk and liability, and to meet regulatory requirements (Bosona \& Gebresenbet, 2013; N. Mai et al., 2010). According to N. Mai et al. (2010) food producers were in most cases blamed when something upsets consumers. Product recalls and scandals can be very costly and therefore a main driver for food product traceability (Olsen \& Borit, 2013). According to Aung and Chang (2014) there are several motivating factors or drivers for traceability as can be seen in Figure 3.3. As seen in Figure 3.3 the drivers identified by Aung and Chang (2014) are in line with the driving forces for implementation described by other authors.

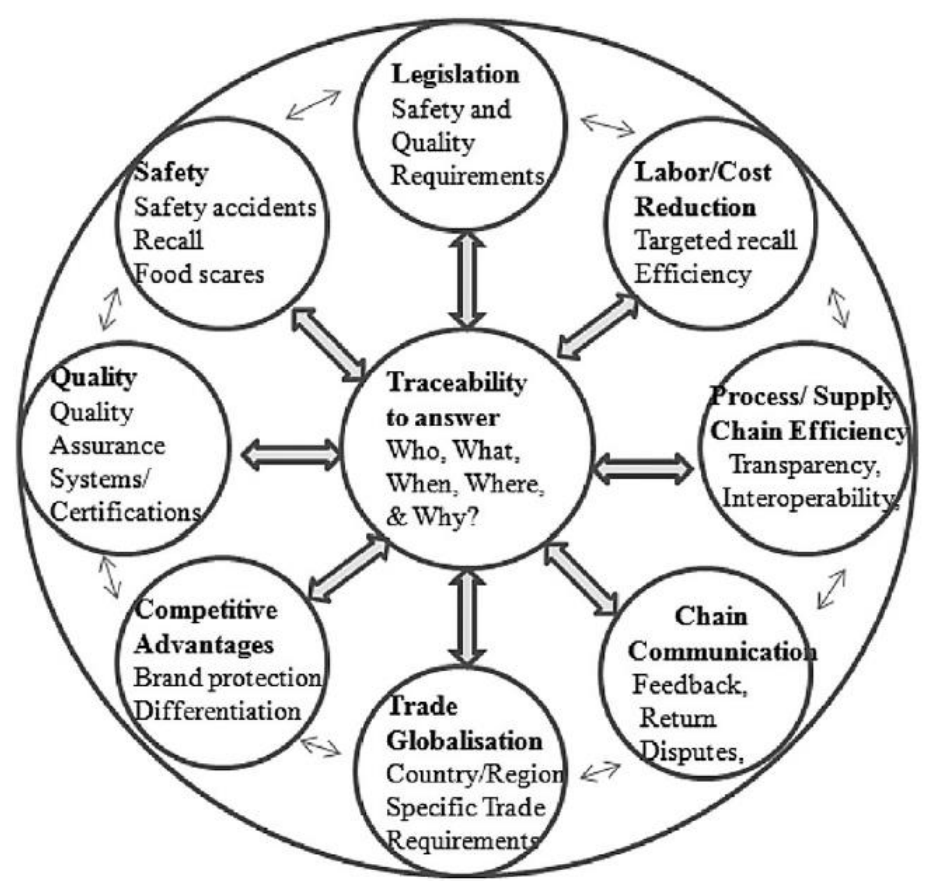

Figure 3.3 Drivers for traceability (Aung \& Chang, 2014). 


\subsubsection{Challenges}

Implementing a traceability system is not without challenges. Previous studies have identified some of the biggest challenges when implementing a traceability system in the food SC. In Table 3.1, possible challenges have been listed according to the main fields: Financial, Operational and Human.

The greatest challenge for food SC managers is the lack of a standardized way to collect information and exchange it among systems used between different actors in the SC (Bhatt et al., 2013; Bosona \& Gebresenbet, 2013; Mgonja et al., 2013; H. Ringsberg, 2014; Storoy et al., 2013). Different actors in the SC can have different technical solutions such as alphanumerical codes, barcodes and radio frequency identification (RFID) tags, leading to compatibility problems (Bosona \& Gebresenbet, 2013). According to Storoy et al. (2013) globalization combined with the complexity of food SC networks has shown the importance of an efficient system used for information exchange between food businesses. However, due to the lack of standardization data handling practice is both time-consuming and costly.

Transparency amongst actors in a SC is also an important factor in every chain and can have its challenges. It effects the data exchange since actors are responsible for maintaining and communicating their own product, process and transformation information (Aung \& Chang, 2014). Companies can see transparency as a risk since shared information can affect competitive attributes in business relationships making mutual trust vital (H. Ringsberg, 2014). 
Table 3.1 Possible challanges when implementing a tracebility system.

\begin{tabular}{|c|c|c|}
\hline Challenges & Why? & Source \\
\hline \multirow[t]{4}{*}{ Financial } & High implementation cost & (Bhatt et al., 2013; Bosona \\
\hline & o 1 - & $\begin{array}{l}\text { \& Gebresenbet, 2013; } \\
\text { Pizzuti \& Mirabelli, 2015; } \\
\text { H. Ringsberg, 2014) }\end{array}$ \\
\hline & $\begin{array}{l}\text { Return on investment (ROI) not } \\
\text { guaranteed }\end{array}$ & (Bhatt et al., 2013) \\
\hline & Confidentiality concerns & (Aung \& Chang, 2014) \\
\hline \multirow[t]{6}{*}{ Operational } & Lack of standards to collect and exchange & (Bhatt et al., 2013; Bosona \\
\hline & information with other actors in the SC & $\begin{array}{l}\text { \& Gebresenbet, 2013; } \\
\text { Mgonja et al., 2013; H. } \\
\text { Ringsberg, 2014; Storoy et } \\
\text { al., 2013) }\end{array}$ \\
\hline & Lack of systems interoperability & $\begin{array}{l}\text { (Bhatt et al., 2013; H. } \\
\text { Ringsberg, 2014) }\end{array}$ \\
\hline & Lack of appropriate infrastructure & (H. Ringsberg, 2014) \\
\hline & $\begin{array}{l}\text { Inability to keep track of product } \\
\text { transformation (mixing, splitting...) } \\
\text { Lack of proper identification of products }\end{array}$ & $\begin{array}{l}\text { (Aung \& Chang, 2014; } \\
\text { Storoy et al., 2013) } \\
\text { (Storoy et al., 2013) }\end{array}$ \\
\hline & $\begin{array}{l}\text { Extensive manual exchange of } \\
\text { information }\end{array}$ & (Aung \& Chang, 2014) \\
\hline \multirow[t]{6}{*}{ Human } & Lack of technical knowledge & (Bhatt et al., 2013; Bosona \\
\hline & & $\begin{array}{l}\text { \& Gebresenbet, 2013; } \\
\text { Pizzuti \& Mirabelli, 2015; } \\
\text { H. Ringsberg, 2014) }\end{array}$ \\
\hline & Lack of trust in the SC for transparency & $\begin{array}{l}\text { (Aung \& Chang, 2014; } \\
\text { Bhatt et al., 2013; H. } \\
\text { Ringsberg, 2014) }\end{array}$ \\
\hline & Resistance to change and willingness & $\begin{array}{l}\text { (Bosona \& Gebresenbet, } \\
\text { 2013; H. Ringsberg, 2014) }\end{array}$ \\
\hline & Lack of awareness for potential gain & $\begin{array}{l}\text { (Bosona \& Gebresenbet, } \\
\text { 2013; H. Ringsberg, 2014) }\end{array}$ \\
\hline & Use of new technology & $\begin{array}{l}\text { (Pizzuti \& Mirabelli, } \\
\text { 2015) }\end{array}$ \\
\hline
\end{tabular}

\subsubsection{Benefits}

Implementing a traceability system can have its challenges. Nevertheless, if an effective traceability system is adopted a few possible benefits can be achieved. These benefits are compiled in Table 3.2 where they are sorted into eight fields: Market, Recall, Liability, Process, Labor, Reputation and Financial. Previous studies have shown that the main benefits of traceability are related to product and process improvements that lead to a reduction of production costs, risk of recalls and incidents (N. Mai et al., 2010). It also provides an opportunity to communicate to the consumer the diligence of the company that leads to a protection of the brand name (Aung \& Chang, 2014). According to Pizzuti and Mirabelli (2015) benefits have a greater weight than challenges, if compared. 
Table 3.2 Possible benefits when implementing a traceability system.

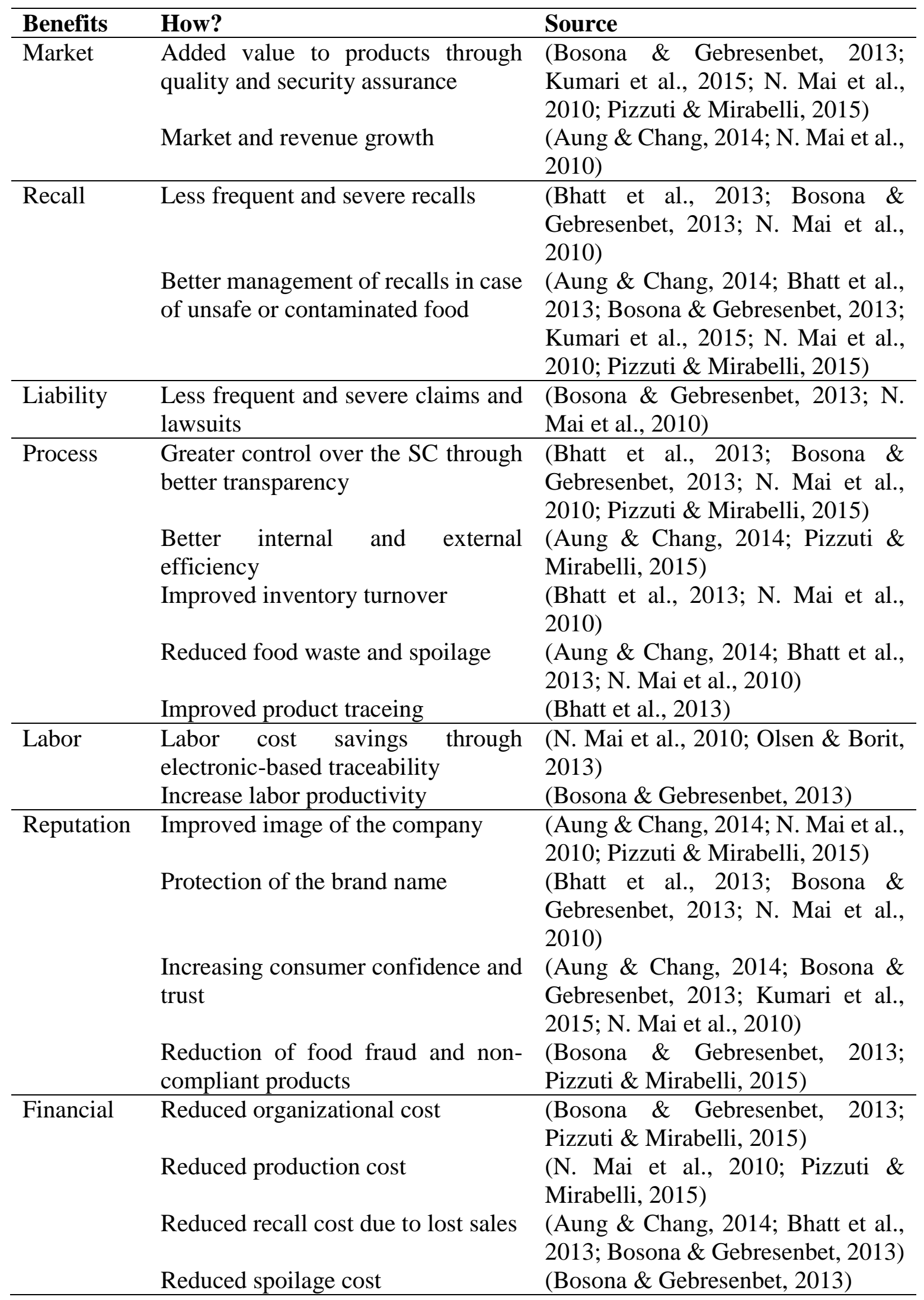


Recent improvements in electronic systems and standardization in food product traceability has led to some potential benefits other than just reducing risk and meeting requirements. The potential benefits can be (Olsen \& Borit, 2013):

- Reducing the cost and labor related to better information and less rework of data internally;

- Reducing the cost and labor related to exchange of information between business actors through a better integration of electronic systems;

- More accurate and timely information that is needed to make better production decisions;

Bhatt et al. (2013) also talked about how automation of processes and data standards could improve the speed of reporting. Showing that electronic traceability system can have even more benefits.

\subsection{Legislations for food traceability}

There are two leading players when it comes to enforcing legislations connected with food traceability, the European Union and the United States (Aung \& Chang, 2014).

\subsubsection{European legislation}

The European traceability framework is regulated at three levels: European Commission policies, country level policies and standards, and private voluntary certification. The last one is certified by private companies (Dabbene et al., 2014).

In the European Union, there are legal requirements for food traceability and food traceability systems set by the European Commission. These requirements are specified in the European General Food Law specifically regulation no. 178/2002 (EU, 2002), which was enforced January the $1^{\text {st }} 2005$ and it requires mandatory traceability for all food and feed products sold within the European Union countries (Aung \& Chang, 2014; Dabbene et al., 2014; H. A. Ringsberg \& Mirzabeiki, 2014; Zhang \& Bhatt, 2014).

According to the legislation it is required that traceability systems are established at all stages of food production, processing, storage and distribution. Likewise, it is required to apply the "one-step-forward-one-step-back" approach (Bosona \& Gebresenbet, 2013; N. T. T. Mai et al., 2010; Storoy et al., 2013). This approach declares that each actor has to be able to answer two questions: "From whom were the ingredients and food/feed obtained?" and "To whom were the products sold?". Thus, ensuring a whole SC traceability. The concept is illustrated in Figure 3.4.

The General Food Law also requires that the food or feed is labeled adequately before it is placed on the market (Bosona \& Gebresenbet, 2013). The legislation does however not specify detailed methods or specific techniques that should be followed by the SC actors (Bosona \& Gebresenbet, 2013; Dabbene et al., 2014; Olsen \& Borit, 2013). 


\section{Supplier?}

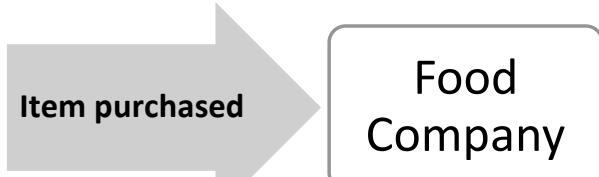

Item produced

Recipient?

Figure 3.4 The "one-step-forward-one-step-back" approach

\subsubsection{United States of America legislation}

In the United States of America, mandatory rules on food traceability are set forward in the Bioterrorism Act of 2002. These rules where written due to increased risk of bioterrorism threats and where therefore enforced $12^{\text {th }}$ of June 2002 (U.S. Food and Drug Administration, 2002). Before that, traceability was not regulated but private companies could assure safety of food products through traceability solutions (Dabbene et al., 2014; Gessner et al., 2007; H. A. Ringsberg, 2015). The Bioterrorism Act mentions that the person who manufactures, processes, packs, transports, distributes, receives, holds or imports food must register with the Food and Drug Administration (FDA), establish and maintain records for food traceability to identify previous sources and subsequent recipients (Aung \& Chang, 2014; Gessner et al., 2007; Storoy et al., 2013; Zhang \& Bhatt, 2014).

On $4^{\text {th }}$ of January 2011 the FDA's Food Safety Modernization Act (FSMA) was enforced (U.S. Food and Drug Administration, 2011). It requires food and feed facilities to evaluate the food safety hazards and to identify and implement preventive actions at those points (Aung \& Chang, 2014). It also states that it is mandatory to label the source of the food. The aim is to ensure safety by preventing contamination rather than responding to recalls, therefore making the food SC more electronic and transparent (Chen et al., 2014).

\subsection{Standards for food traceability}

The use of standards for food traceability has increased significantly in the last decade $(\mathrm{H}$. A. Ringsberg, 2015). Organizations such as International Standardization Organization (ISO), Codex Alimentarius Commission (CAC) and Global Standardization Organization 1 (GS1) have been founded to establish guidelines for traceability and developing standards (Aung \& Chang, 2014; H. A. Ringsberg, 2015). It is said that traceability can only be fully accomplished if it is built upon standardized approaches that enable interoperability between traceability systems across a global SC (Aung \& Chang, 2014; H. A. Ringsberg, 2015).

\subsubsection{International traceability standards}

\section{International Standardization Organization}

ISO is the world's largest developer and publisher of international standards. ISO standards provide a uniformity and prevent that technical barriers hinder trading around the world (Aung \& Chang, 2014). The structure of the standards is based on the terms: shall (mandatory), should (recommended) and may (optional) (H. A. Ringsberg, 2015).

ISO has published several standards concerning food traceability mainly based on the ISO 9000 series for Quality Management System. Food safety requirements are addressed in ISO 22000: 2005 and principles and basic requirements for designing and implementing food 
traceability systems are included in ISO 22000: 2007 (H. A. Ringsberg, 2015). The food safety standard requires "one-step-forward-one-step-back" (Aung \& Chang, 2014; Storoy et al., 2013).

\section{Codex Alimentarius Commission}

The CAC was founded by the Food and Agriculture Organization of the United Nations (FAO) and the World Health Organization (WHO) (Codex Alimentarius Commission, 2015) to protect the public health and to serve as a guideline for food SC's (H. A. Ringsberg, 2015).

The CAC standards range from characteristics of raw and processed materials, to food hygiene, contaminants and pesticides, labelling and methods of analysis and sampling. The CAC standard recommends the usage of the Hazard Analysis Critical Control Point (HACCP) as it is an effective system to maintain quality assurance (Aung \& Chang, 2014; H. A. Ringsberg, 2015).

\section{Global Standardization Organization 1}

GS1 is formerly known as the EAN.UCC (European Article Numbering - Uniform Code Council). A common global standard for open codes did not exist until these two organizations formed the GS1 standard (Chrysochou et al., 2009). The GS1 standard provides globally unique identifications for traceable units such as batches, trade units, logistic units and the location. This makes the GS1 standard well suited to be used for traceability purposes as it meets basic legal and business requirements for food traceability (Aung \& Chang, 2014; H. A. Ringsberg, 2015). One of the information standards provided by the GS1 is the open Electronic Product Code Information Service (EPCIS) standard that uses Electronic Product Code (EPC) identity keys (H. A. Ringsberg, 2015; H. A. Ringsberg \& Mirzabeiki, 2014). 



\section{Identification technologies used in traceability}

The most common types of identification technologies that capture data in the food SC are paper records, barcodes, radio frequency identification (RFID) and electronic systems. Of these the alphanumerical codes, barcodes and RFID are fundamental techniques available for traceability (Bosona \& Gebresenbet, 2013). RFIDs and wireless sensor networks (WSNs) have been considered as the key technological enablers (Zou et al., 2014) and many cold chains monitoring temperature are using RFIDs, sensors and wireless technology as they show benefits in quality, safety and optimizing the SC (Trebar et al., 2013).

As pointed out by Badia-Melis et al. (2016) "current cold chain monitoring systems in use today lack the ability to provide a real-time, accurate information relating to the products and the conditions in which they are at any given moment in time.". Since RFIDs and WSN can provide this option, these techniques have begun to be considered more often in cold chain applications.

\subsection{Paper records}

A simple pen and paper traceability is frequently used to monitor stock information, report and communicate across the SC (Dandage et al., 2017). The paper-based systems are still widely used as traceability systems in both large and small companies (Aung \& Chang, 2014; Parreno-Marchante et al., 2014). This type of traceability requires a considerable amount of manual work, which is time consuming and can lead to errors (Dandage et al., 2017; ParrenoMarchante et al., 2014). This results in a low level of efficiency (Mgonja et al., 2013; H. A. Ringsberg \& Mirzabeiki, 2014) and difficulties in fulfilling legal food traceability requirements (H. A. Ringsberg \& Mirzabeiki, 2014).

\subsection{Alphanumerical codes}

Alphanumerical codes consist of a label that includes a combination of numbers and letters of various sizes (Aung \& Chang, 2014; Dandage et al., 2017). This is both simple and economic (Aung \& Chang, 2014). According to Bosona and Gebresenbet (2013) alphanumerical codes are not a frequently used technology nowadays. Since they are not automatic, they require significant human resources and costs. This is because each code must be read and written leading to a poor performance and the possibility of errors. There are no standards defined so a lack of cohesion arises. Furthermore, since there is no sensing capability, there is no way to collect environmental factors automatically (Aung \& Chang, 2014). 


\subsection{Holograms}

According to Dandage et al. (2017) a hologram is defined as "a physical structure that diffracts light into an image, while it refers for both the encoded material and the resulting image". Holograms can be an effective way to test product authenticity to identify genuine products from fake, see Figure 4.1 (Dandage et al., 2017).
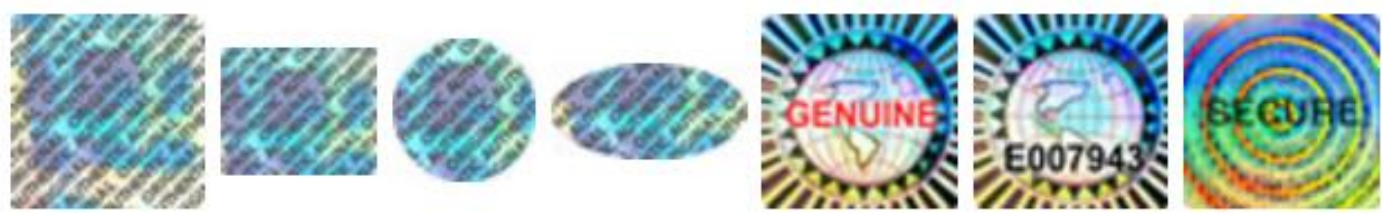

Figure 4.1 Example of different holograms (NovaVision, 2017).

\subsection{Barcodes}

The barcode system is a universally known traceability information carrier applied in the food SC. It is one of the best known and commonly used traceability carriers according to Chrysochou et al. (2009). Barcodes use open standards such as EAN, UCC and the GS1 (Bosona \& Gebresenbet, 2013; Chrysochou et al., 2009).

Aung and Chang (2014) describe a barcode as an "optical machine readable representation of data" which "encodes alphanumeric characters and consist of vertical bars, spaces, squares and dots". Barcodes can be both one-dimensional (1-D), see Figure 4.2, and twodimensional (2-D), see Figure 4.3 (Parreno-Marchante et al., 2014). The 1-D barcodes are called linear barcodes while the 2-D are called quick response (QR) codes (Dandage et al., 2017). QR codes are similar to linear barcodes but they require a $Q R$ code reader (Costa et al., 2013). QR codes are able to store more information than 1-D barcodes as they can store data in both the horizontal and vertical direction. A single QR code symbol can contain up to 7.089 numerals, over 200 times more than a traditional 1-D barcode (Denso ADC, 2011).

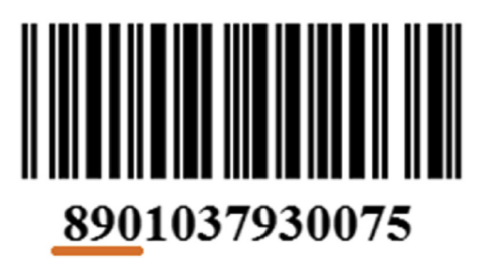

Figure 4.2 An Indian GS1 barcode identifiable by the 890 digits (Dandage et al., 2017). 


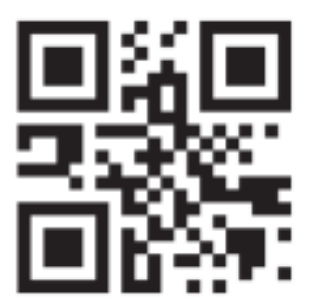

Figure 4.3 QR (Quick Response) code (Denso ADC, 2011).

Barcodes are simple, economical and provide decent traceability. The main advantages of barcodes is the simplicity and low implementation cost (Chrysochou et al., 2009). A typical barcode label costs less than 1 cent (Kumar et al., 2009; Ruiz-Garcia \& Lunadei, 2011).

Whereas, the main drawback of this technology is the need for line of sight (Aung \& Chang, 2014) as the label needs to be positioned so that the reader can detect and identify it (Mgonja et al., 2013) this requires considerable human intervention which can lead to errors and inefficiency (Bosona \& Gebresenbet, 2013; Mgonja et al., 2013). The reader cannot detect damaged labels and can only read one label at a time (Aung \& Chang, 2014). However, QR codes do not require alignment as they can be read from any $360^{\circ}$ angle and can decode a symbol even if $30 \%$ of the data is dirty or damaged (Denso ADC, 2011).

Another drawback of the barcode is that it cannot collect environmental information, as there is no sensing capability (Aung \& Chang, 2014). Furthermore, the limited storage capability limits the amount of data (Chrysochou et al., 2009).

\subsection{Intelligent packaging}

Intelligent packaging (IP) or smart packaging can be defined as "a packaging system that is capable of carrying out intelligent functions (like detecting, sensing, recording, tracing, communicating and applying scientific logic) to facilitate decision making, to extend shelf life, enhance safety, improve quality, provide information and warn about possible problems" (Heising et al., 2014).

IP consists of technologies such as sensors and indicators to estimate and communicate the quality of food to costumers (Bosona \& Gebresenbet, 2013; Heising et al., 2014). Heising et al. (2014) classified IP into three types: Data carriers which store and transmit data, Environmental Indicators which can monitor the external or internal environment and issue warnings if the package is damaged or contaminated and finally Quality Indicators which monitor quality attributes of the product itself and they are usually placed inside the package. An illustration of the environmental and quality indictor can be seen in Figure 4.4. 


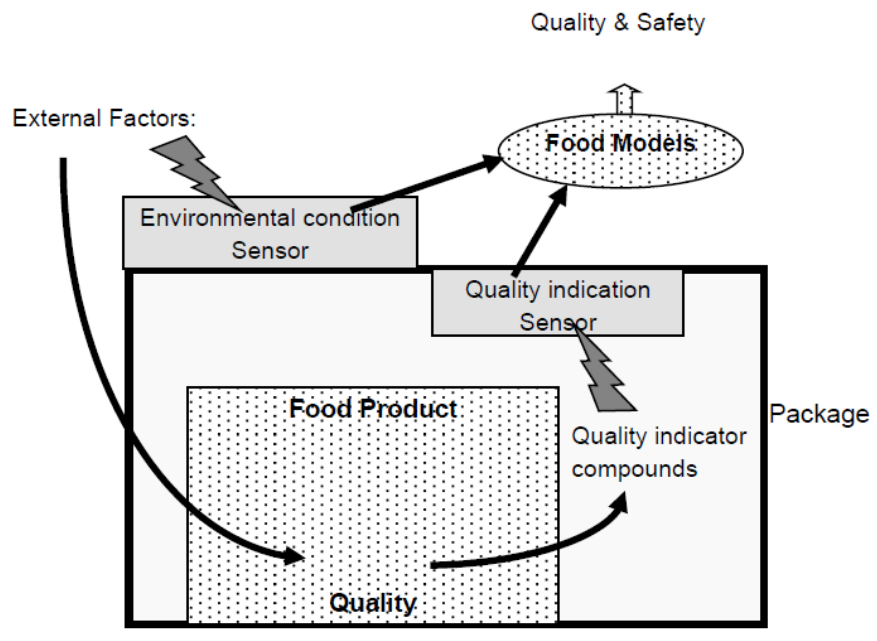

Figure 4.4 Illustration of environmental and quality indicators in IP (Heising et al., 2014).

Time temperature indicators (TTI) and gas leakage indicators are examples of environmental monitors while freshness indicators and biosensors are examples of quality indicators (Heising et al., 2014). A short definition of these technologies is listed below:

- TTI: Indicates the temperature history during storage and distribution, they are small, cheap, simple, easily integrated and reliable but it is hard to know the initial quality, see Figure 4.5 (a) (Fuertes et al., 2016; Giannoglou et al., 2014; Heising et al., 2014; Mohebi \& Marquez, 2015);

- Gas leakage indicator: Monitors the gas composition inside the package for changes and toxicity (Bosona \& Gebresenbet, 2013; Fuertes et al., 2016; Mohebi \& Marquez, 2015);

- Freshness indicator: Estimates the remaining shelf life of a product by indicating the quality using microbial growth or time, see Figure 4.5 (b) (Bosona \& Gebresenbet, 2013; Fuertes et al., 2016; Mohebi \& Marquez, 2015);

- Biosensor: Information about biochemical reactions are detected, recorded and transmitted using electric signals, they are small, accurate, economical and easy to understand and operate (Bosona \& Gebresenbet, 2013; Mohebi \& Marquez, 2015);

Other sensors and indicator include electronic noses and fluorescence-base oxygen sensors (Mohebi \& Marquez, 2015). Embedded RFID tags with sensors have also been mentioned as a solution for IP, for details on RFID see Chapter 4.6 (Fuertes et al., 2016; Heising et al., 2014; Mohebi \& Marquez, 2015). 


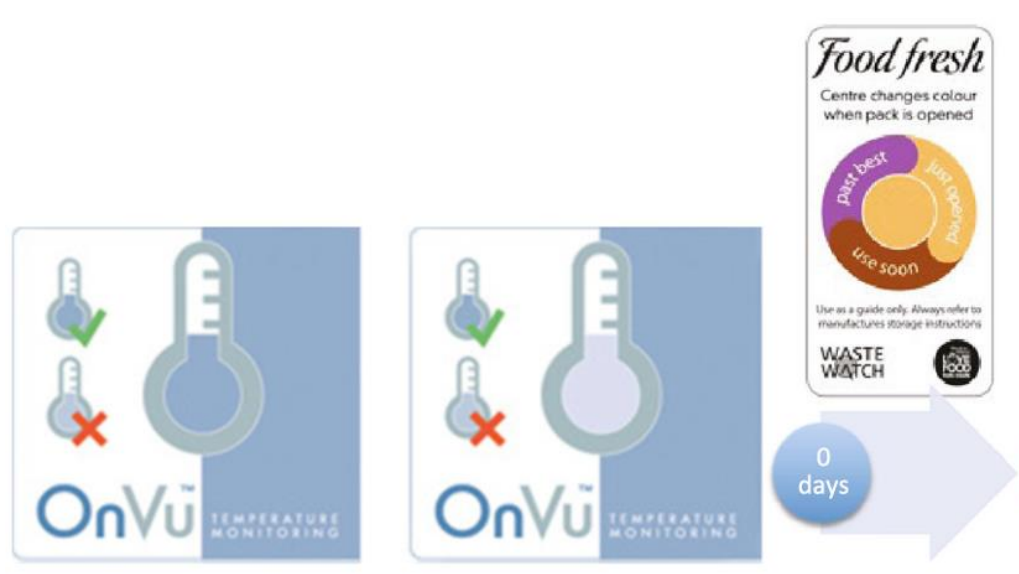

(a)

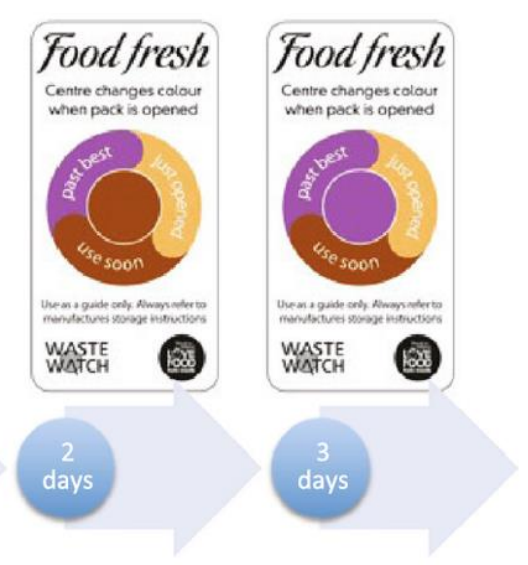

(b)

Figure 4.5 Examples of indicators: (a) TTI (b) Freshness indicator (Mohebi \& Marquez, 2015).

\subsection{Radio Frequency Identification}

RFID systems are an emerging technology that make use of wireless communication. They were originally developed for short-range product identification, with around $2 \mathrm{~mm}-2 \mathrm{~m}$ reading range. RFID tags are said to have a strong potential of replacing the barcode technology, with the use of EPC (Ruiz-Garcia et al., 2009). It is only in the last two decades that RFIDs have started to receive more attention and it is expected to rise in the near future (Chrysochou et al., 2009). There are various standards involved for RFIDs e.g. the ISO standards and EPCglobal (Kumari et al., 2015; Ruiz-Garcia et al., 2009).

An RFID system consists of two main components a tag (transponder) and a reader (transceiver or interrogator) that reads and writes data to the transponder (Fuertes et al., 2016; Ruiz-Garcia et al., 2009). The RFID tag consists of an integrated circuit that stores a unique identification number, an antenna connected to a microchip and a memory chip. The circuit is protected from dust, extreme temperatures, moisture and salt with coating. The tag interacts with the reader that is connected to a computer system. The reader uses radio waves to read data from the RFID tag, the data is then converted into digital form by the reader that is added into an information system hosted on a computer system (Bosona \& Gebresenbet, 2013). Readers can be either handheld computers or fixed devices to a specific place (Fuertes et al., 2016).

RFID tags are classified into three categories: Active, passive and semi-passive (Figure 4.6). Passive and semi-passive RFIDs transmit their data by harvesting energy from the radio waves sent by the reader and utilizing it for the data transmission. The reading range is typically between $10 \mathrm{~cm}$ and $3 \mathrm{~m}$. Passive RFIDs are low cost (around 10 cents for large quantities) with an unlimited lifetime. Semi-passive RFIDs and active RFIDs have a battery so the lifetime of the tag is dependent on the battery. The battery of a semi-passive RFID is only used to run the circuit of its microchip and is activated by the signal form the reader, otherwise it is in sleep mode and saves power. The battery power is not used to transmit the data. While the battery of an active RFID powers up the microchip and is used to transmit 
the data (Kumar et al., 2009; Kumari et al., 2015; Ruiz-Garcia et al., 2009). These tags have higher signal strength leading to a communication range of up to 100 meters, but this requires larger batteries and more electronic components than for semi-passive RFIDs. The typical price of active RFIDs is between five or ten times the price of semi-passive ones (RuizGarcia et al., 2009). In applications such as cold chain monitoring semi-passive and active tags are commonly used (Kumari et al., 2015) as they can support sensors allowing for realtime information transfer (Laniel et al., 2011).

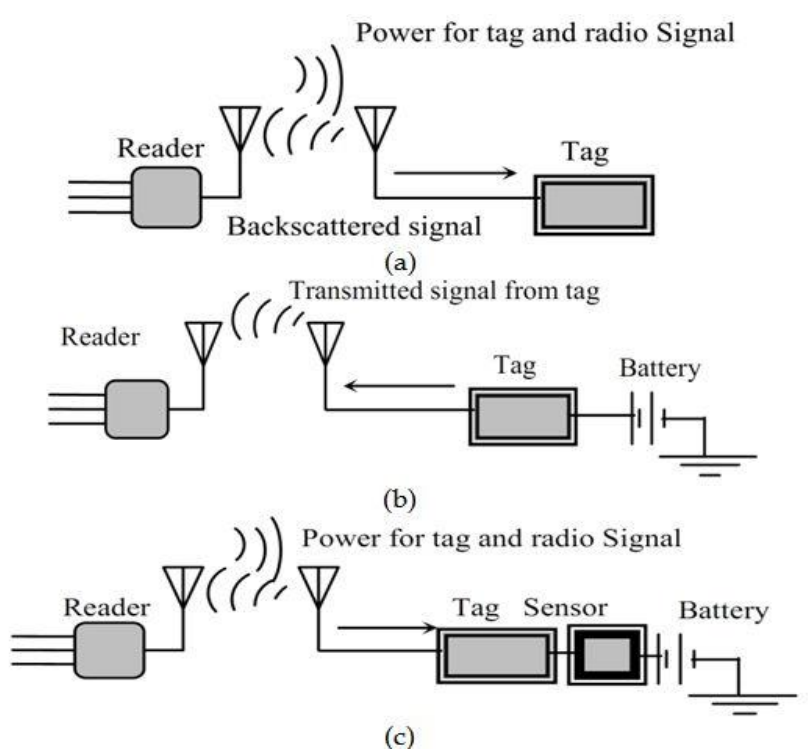

Figure 4.6 Different categories of RFID tags (a) passive, (b) active and (c) semi-passive adopted from Khan et al. (2009).

The reading distance depends on the frequency band the RFIDs work on (Bosona \& Gebresenbet, 2013; Fuertes et al., 2016; Kumari et al., 2015; Ruiz-Garcia \& Lunadei, 2011):

- Low frequency $(\mathbf{L F})$ band (125-134.2 kHz): Minimum interference from liquids or metals and a limited reading range and slow data speed. Available in most countries;

- High frequency (HF) band $(13.56 \mathrm{MHz})$ : Greater reading range and higher data speed, have been applied in cold chains. Available worldwide;

- Ultra-high frequency (UHF) band (433 $\mathrm{MHz}$ worldwide, 865.5-867.6 $\mathrm{MHz}$ in Europe and $915 \mathrm{MHz}$ in USA): Even better reading range than LF and $\mathrm{HF}$, faster data speed and a good anti-collision capability, popular for SC and logistics. $433 \mathrm{MHz}$ works better with metals and liquids compared to $865.5-867$ and $915 \mathrm{MHz}$;

- Microwave $(2.4 \mathrm{GHz}$ or $5.8 \mathrm{GHz}$ ): Highest data rate and fast identification, high cost and inability to penetrate metals or liquids, lower reading range. $2.4 \mathrm{GHz}$ has more potential interference than UHF as other technologies such as Bluetooth use the band. Available worldwide;

Not all RFID tags work on every frequency band, in Table 4.1, tags have been classified based on the frequency. The typical and maximum communication range is shown as well. In general, when choosing the right frequency according to Ruiz-Garcia and Lunadei (2011), 
the higher the frequency, the longer the communication range and the faster the communication, this means that more data can be transmitted.

Table 4.1 Classification of RFID tags based on frequency adopted from Ruiz-Garcia and Lunadei (2011).

\begin{tabular}{|c|c|c|c|c|}
\hline \multirow[t]{2}{*}{ Frequency } & \multirow[t]{2}{*}{ Common frequency } & \multirow[t]{2}{*}{ Tag type } & \multicolumn{2}{|c|}{ Range } \\
\hline & & & Typical & Maximum \\
\hline$\overline{\mathrm{LF}}$ & $125-134.2 \mathrm{kHz}$ & Passive & $20 \mathrm{~cm}$ & $1 \mathrm{~m}$ \\
\hline $\mathrm{HF}$ & $13.56 \mathrm{MHz}$ & $\begin{array}{l}\text { Passive and semi- } \\
\text { passive }\end{array}$ & $10 \mathrm{~cm}$ & $1.5 \mathrm{~m}$ \\
\hline \multirow[t]{2}{*}{ UHF } & $433 \mathrm{MHz}$ & Active & $3 \mathrm{~m}$ & $10 \mathrm{~m}$ \\
\hline & $865.5-867,915 \mathrm{MHz}$ & $\begin{array}{l}\text { Passive, semi-passive } \\
\text { and active }\end{array}$ & $3 \mathrm{~m}$ & $15 \mathrm{~m}$ \\
\hline Microwave & 2.4 and $5.8 \mathrm{GHz}$ & $\begin{array}{l}\text { Passive, semi-passive } \\
\text { and active }\end{array}$ & $3 \mathrm{~m}$ & $30 \mathrm{~m}$ \\
\hline
\end{tabular}

According to Ruiz-Garcia et al. (2009) RFID technology has been successfully applied to food logistics and SC management processes because of its ability to identify, categorize, and manage the flow of goods. This is due to the fact that RFID requires no line of sight and has the ability to read and write many tags at a time. Furthermore, they also have high data rate and large memories compared to other identification technologies and are small in size with a good reading distance (Aung \& Chang, 2014; Bosona \& Gebresenbet, 2013; Chrysochou et al., 2009; Fuertes et al., 2016; Ruiz-Garcia et al., 2009). Other advantages include reduced labor cost and operational costs, stock reduction, lower rate of recalls, automated scanning, better inventory tracking and forecasting (Kelepouris et al., 2007; Kumar et al., 2009; Parreno-Marchante et al., 2014). RFIDs allow alerts to be triggered so the receiver can know immediately if there is a problem and not afterwards (Laniel et al., 2011). However, the full potential of RFID will only be achieved when all actors in the SC implement the technology (Kelepouris et al., 2007).

A couple of disadvantages of RFID technology is the need for a reader to collect data, the fact that tags are not able to cooperate with each other and cannot initiate a communication with a reader. Environmental conditions such as water, great cold and metal objects can disturb the reading of tags (Aung \& Chang, 2014; Bosona \& Gebresenbet, 2013; Chrysochou et al., 2009). There is a lack of worldwide standards between countries, e.g. an ultra-high frequency tag in Europe would not work in USA (Badia-Melis et al., 2015; Kumar et al., 2009). RFIDs are also environmentally unfriendly as it is hard to recycle the components. Security concern have been mentioned as whoever can scan a tag with a reading device and thereby get access to private information (Kumar et al., 2009). However, in order to circumvent this issue encryption solutions have been proposed (Kumari et al., 2015). Nevertheless, the main disadvantage is its high costs. This high cost means that mainly high value products have the potential to exploit RFID tags (Chrysochou et al., 2009) e.g. a product like cereal is unlikely to benefit from RFID as it is a low value bulk product (Gessner et al., 2007).

Despite all these challenges RFID technology is recognized as the most cutting edge technology for SC integrity and traceability. However, the problem is still the high cost of tags, even though the prices have decreased significantly in recent years (Aung \& Chang, 
2014). The long-term vision are printable RFID tags onto papers and plastics and not silicon, nevertheless inkjet printed circuits currently have a low resolution which results in a large amount of coverage compared to traditional fabricated circuits (Sharma \& Panwar, 2014). Recent developments in combining RFID and sensors (e.g. temperature) extend its range of application especially in the cold chain (Ruiz-Garcia et al., 2009).

\subsection{Wireless Sensor Networks}

WSN have been applied in many sectors, e.g. in food cold chain logistics and agriculture, environmental monitoring and heavy industry (Xiao et al., 2016). WSN are promising for cold chain applications as they can provide real-time information on perishable foods at a reasonable cost and good performance (Wang et al., 2015) throughout the whole SC (Hafliðason et al., 2012). A variety of sensors are available for sensing and monitoring food safety and quality such as temperature, humidity and vibration (Aung \& Chang, 2014; Costa et al., 2013; Wang et al., 2015). The sensor accuracy is critical to be able to detect early on temperature changes in cold chains, allowing a deviation of $\pm 0.5^{\circ} \mathrm{C}$ from the set point according to food standards (Hafliðason et al., 2012).

A WSN represents a network of sensors that forms a system that collects and transmits sensing data from physical or environmental conditions (Aung \& Chang, 2014; Costa et al., 2013). A WSN consists of several sensor nodes that communicate with a base station (central node). The base station collects the data from the sensors and sends it via a mobile network like GPRS (General Packet Radio Service) to a central station, see Figure 4.7 (Costa et al., 2013; Hafliðason et al., 2012; Ruiz-Garcia et al., 2009). Large volumes of data are transmitted in real-time resulting in heavy data traffic. This effects the processing of data and could affect the collection and transmission efficiency resulting in inefficient data gathering (Xiao et al., 2016).

Sensors have a limited processing capability and memory (Hafliðason et al., 2012) but one of their strengths is the ability to exchange data with each other (Costa et al., 2013) through a multi hop network and different kinds of network topologies that ensure communication among sensors (Aung \& Chang, 2014) in case a sensor cannot contact the base station (RuizGarcia et al., 2009) which in turn results in low error rates. This is the main difference between a WSN and RFID systems as RFID devices have no cooperative capabilities (RuizGarcia et al., 2009). WSN have longer reading ranges than RFID but are not suitable for identification purposes like RFID (Aung \& Chang, 2014).

The cost and power consumption of WSN nodes have dropped substantially in the past years due to the progress of microelectronics technologies (Wang et al., 2015), this offers opportunities for battery driven base stations and thus getting rid of all wiring (Hafliðason et al., 2012). The sensors fall into sleep mode after a successful data emission but they wake up and transmit at regular intervals (Xiao et al., 2016), this is done to prolong the battery life and requires special energy saving techniques (Aung \& Chang, 2014). Low temperatures have a negative effect on the battery life of sensors (Ruiz-Garcia et al., 2009). 


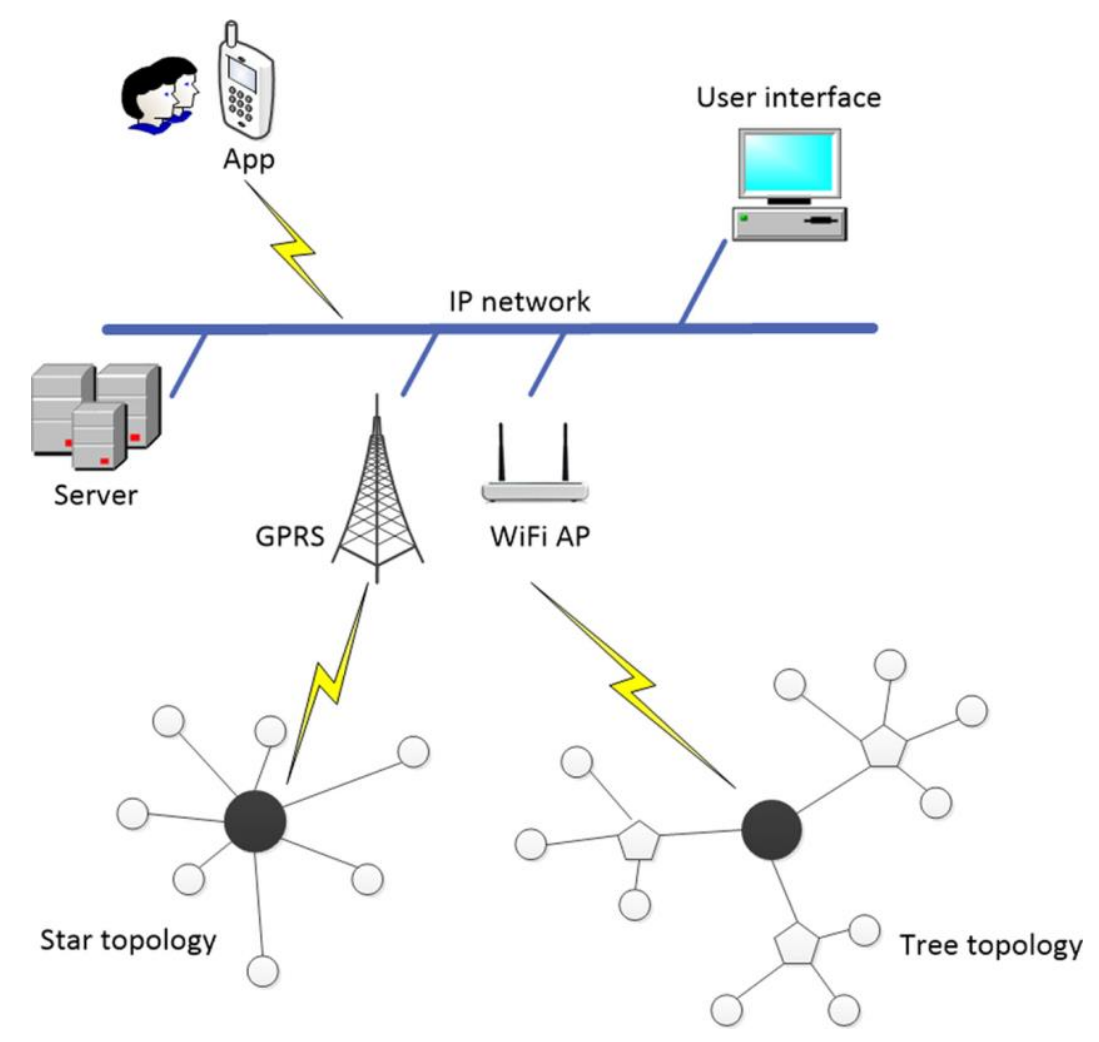

Figure 4.7 Conceptual framework of a Wireless Sensor Network (Wang et al., 2015).

To prolong the battery life of sensors, protocols such as ZigBee have been devised as it requires low energy consumption and has advanced network capabilities (Ruiz-Garcia et al., 2010). The ZigBee protocol is built on the IEEE 802.15.4 standard so it fulfills specifications for different network topologies and provides a user friendly framework (Wang et al., 2015). ZigBee physical layer supports three frequency bands; $2.4 \mathrm{GHz}, 915 \mathrm{MHz}$ and $868 \mathrm{MHz}$ The Industrial, Scientific and Medical (ISM) band of $2.4 \mathrm{GHz}$ provides a license free operations and a worldwide compatibility (Ruiz-Garcia et al., 2009). However, $868 \mathrm{MHz}$ is license free in Europe and $915 \mathrm{MHz}$ in America.

Another technology available for WSN is Bluetooth, which also works on the ISM band. Bluetooth however has a high-power consumption making it not suitable for ultra-low power consumption applications contrary to the ZigBee protocol that was developed for low power consumption and extension of battery life. ZigBee also provides more flexibility and allows for larger number or nodes (Ruiz-Garcia et al., 2009).

\subsection{Further investigation}

To further investigate whether the literature gathered is consistent with technologies available right now in the market an online web search was carried out. This resulted in supplementary information e.g. regarding price of the different technologies and an additional technological option for a passive RFID tag that has temperature sensing capabilities, see Table 4.2. According to Kumari et al. (2015) semi-passive and active RFID are commonly used in cold chain applications as they can support sensors but according to the investigation passive RFID with temperature sensing capabilities are also available. This allows for even more capabilities at an affordable price. It should be noted that the price is 
always dependent on the number of tags ordered, meaning that a larger order would result in lower prices per tag.

Table 4.2 Current market price per tag.

\begin{tabular}{|c|c|c|}
\hline Technology & Price per tag & Source \\
\hline TTI tag & $\$ 0.91-\$ 5.50$ & $\begin{array}{l}\text { (TGoldkamp, 2017; TIP } \\
\text { Products, 2017a, 2017b) }\end{array}$ \\
\hline Passive RFID tag & $\$ 0.124-\$ 0.59$ & (atlasRFIDstore, 2017) \\
\hline $\begin{array}{l}\text { Passive RFID tag with } \\
\text { temperature sensor }\end{array}$ & $\$ 0.29-\$ 22.00$ & $\begin{array}{l}\text { (Phase IV Engineering INC., 2016; } \\
\text { RFMicron, 2017) }\end{array}$ \\
\hline $\begin{array}{l}\text { Active RFID tag with } \\
\text { temperature sensor }\end{array}$ & $\$ 36-\$ 51.29$ & $\begin{array}{l}\text { (Red Cell Innovation, 2017; Texim-Europe, } \\
\text { 2017) }\end{array}$ \\
\hline $\begin{array}{l}\text { Wireless temperature } \\
\text { sensor }\end{array}$ & $\$ 49.00$ & (Monnit, 2017) \\
\hline
\end{tabular}




\section{Analysis of Traceability Structures in Cold Chains}

To analyze how traceability techniques are applied in the SC and especially in cold chains a visual mind map was made during the reading of the literature. The mind map was constantly updated after each new observation and a final structure categorizing the traceability techniques began to form, see Figure 5.1. The mapping was done according to the structure mentioned in the methodology chapter, Chapter 2.4, by using the MindManager software from Mindjet. Here, emphasize was put on how to track products and not tracing.

The literature was categorized under the main headings Static traceability and Dynamic traceability. These two main categories where then separated based on their ability to gather data and interact in real-time. Real-time is here defined as "constantly updated data providing information instantaneously", this data should include the temperature level and location of the product. Since not all static technologies have sensing abilities the categories No sensing capability and Sensing capability where added to separate the available technologies. Likewise, not all dynamic traceability techniques can provide a constant realtime functionality and therefore a category called Gateway was defined. The idea behind the gateway is that as the products move throughout the SC the dynamic tag records data and uploads it when it goes through a gate, the gate can be a handover point or some other critical control point. It does therefore not provide real-time data continuously through communication but the data is gathered in real-time throughout the SC and only uploaded at certain predetermined points in the SC. However, the category Real-time does both provide real-time communication and real-time data gathering. In this study, more effort was spent on studying dynamic traceability as the future of traceability lies in the direction of real-time possibilities.

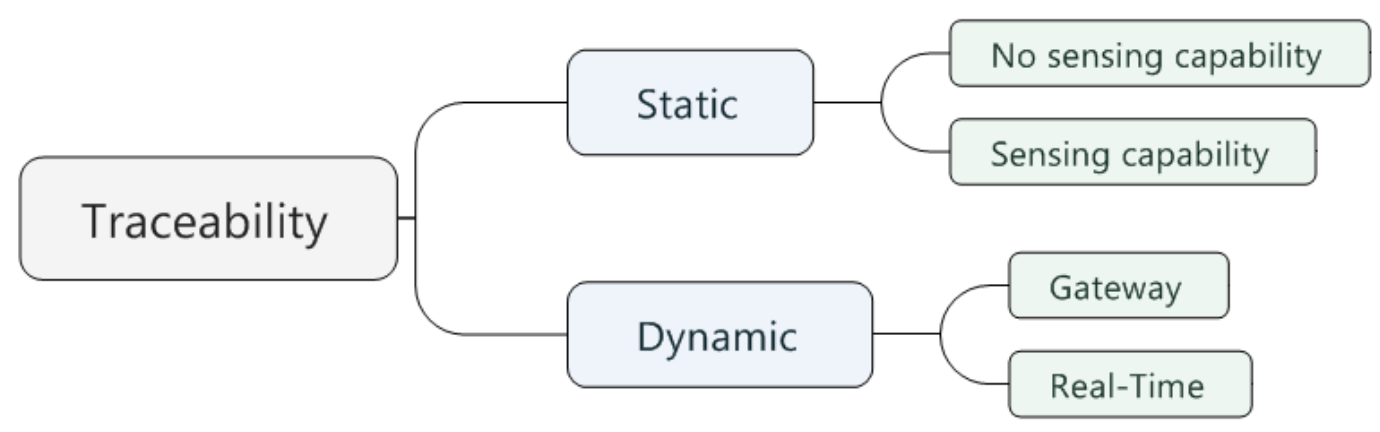

Figure 5.1 Traceability categories formed.

\subsection{Static traceability}

As mention above static traceability was split into No sensing capability and Sensing capability. Both of these are not able to provide real-time communication, which results in an after-the-fact analysis. This can lead to loss of quality and safety of perishable goods, 
even loss of sales as damaged products will not be discovered until too late in the SC leaving no room for remedial actions.

\subsubsection{No sensing capability}

Identification technologies falling under this category are: Paper records, alphanumerical codes, holograms and barcodes. These are all simple technologies but require visual detection, line-of-sight, resulting in considerable manual labor, inefficiency, increased labor cost and human errors (Kumari et al., 2015; Mgonja et al., 2013). Human errors could be a result of oversight or input errors leading to a loss of information (Bertolini et al., 2006). As the government and consumers are demanding more and more transparency, traditional food traceability techniques are not sufficient (Badia-Melis et al., 2015).

Since these static traceability technologies do not possess the ability to sense environmental conditions a substantial quality and safety uncertainty arises for perishable products that need temperature monitoring, because time and temperature are the most important factors for keeping the quality of perishable products and assuring storage life and safety (Kumari et al., 2015). For example, a small change in temperature of fresh chilled fish can affect the quality of perishable goods and thus duplicating the spoilage factor, while a change of $10^{\circ} \mathrm{C}$ can lead to a six-fold increase in the spoilage factor (Heising et al., 2014). This shows how change in environmental conditions of sensitive perishable products can be and how vital sensing capability is in their SC.

\subsubsection{Sensing capability}

Identification technologies falling under this category are intelligent packaging (IP). IP can collect external and internal environmental sensing data such as temperature with the help of TTIs and issue warnings if a desirable temperature goes out of range. IP therefore enhance safety and can guarantee sufficient quality. The classical first-in-first-out policy can now be changed to lowest-quality-first-out, this lowers the percentage of unsold products. However, IP are not able to automatically communicate the environmental data that is gathered in the SC to a traceability system leaving it till the end of the SC where data must be read by the customer either visually or by a computer. IP with an integrated TTI and RFID tag gives the potential of providing real-time communication. In the case of fresh fish, the initial quality level can be variable making it hard to know whether the quality matches what the information provided by the TTI tag. Therefore, a freshness indicator sensing trimethylamine (TMA) can be a good indicator for spoilage of fresh fish as it measures micro-organisms that give off-flavors (Heising et al., 2014).

\subsection{Dynamic traceability}

Dynamic traceability has been divided into Gateway and Real-Time. Both of these categories are able to provide real-time environmental sensing but only Real-Time provides real-time communication. These categories are based on more complicated technologies than static traceability techniques.

The main advantages of dynamic traceability compared to static traceability is to reduce human errors, labor and cost, improve accuracy, inventory and reduce food safety and recall costs (Cuinas et al., 2014; Kumari et al., 2015; N. Mai et al., 2010). This results in more 
effective and efficient systems that gives the SC a globally competitive edge (Kumari et al., 2015).

\subsubsection{Gateway}

Identification technologies falling under Gateway are: RFID. As mentioned before the idea behind the gateway and as the name suggests was some kind of gate that products pass through at different stages in the SC. The dynamic tag on the product records the appropriate data and uploads it when it goes through the gate. The more gates there are in the SC the more overview one can have over of what is happening. Thus, providing more real-time data. One can look at the gates as critical checkpoints, basic checkpoints would include incoming and shipped goods but checkpoints could also be inside a company during e.g. processing.

During transportation, there is a high risk of temperature fluctuation therefore it is critical to have data regarding the incoming goods to see if they have been exposed and damaged at some point in the SC. Most of the studies that have been carried out only look at the temperature data late in the $\mathrm{SC}$ and not during each step. The disadvantage of this procedure is that it is difficult to make fast and informed decisions to avoid losses.

In order to determinate temperature fluctuation in the SC Parreno-Marchante et al. (2014) and Cuinas et al. (2014) used RFID portals to control incoming and outgoing shipments for logistics processes, first to log data about the incoming goods and then to avoid shipment errors for exporting. In their pilot study on aquaculture sea bass, all temperature measurements were stored in RFID data loggers that needed to be scanned to download data into a central sensor service, this was carried out at the end of the rather short SC. The central sensor service confirmed that all temperature readings were within legal limits and triggered an alarm if this was not the case. The end user could scan the product label, which connected them to a webpage that contained all collected data about the product.

In another pilot study on based on sea bass conducted by Trebar et al. (2013) UHF semipassive RFIDs were used to monitor and track from farm to consumer. In their study they used refrigerated trucks for transporting and cold storage of the fish. Each box of fish had an RFID tag with an embedded temperature sensor, which was placed in the boxes at the beginning of the processing step, see Figure 5.2. Fixed RFID readers were used as RFID portals to identify the boxes and verify orders to minimize shipping errors. At the end of the SC the tags were removed from the boxes and temperature data was read and uploaded to a sensor database that can be accessed by users worldwide. These three pilot studies were conducted in a very similar manner the only difference was that in the Trebar et al. (2013) study the RFID tags were intended to be reused making the cost per tag more affordable. 


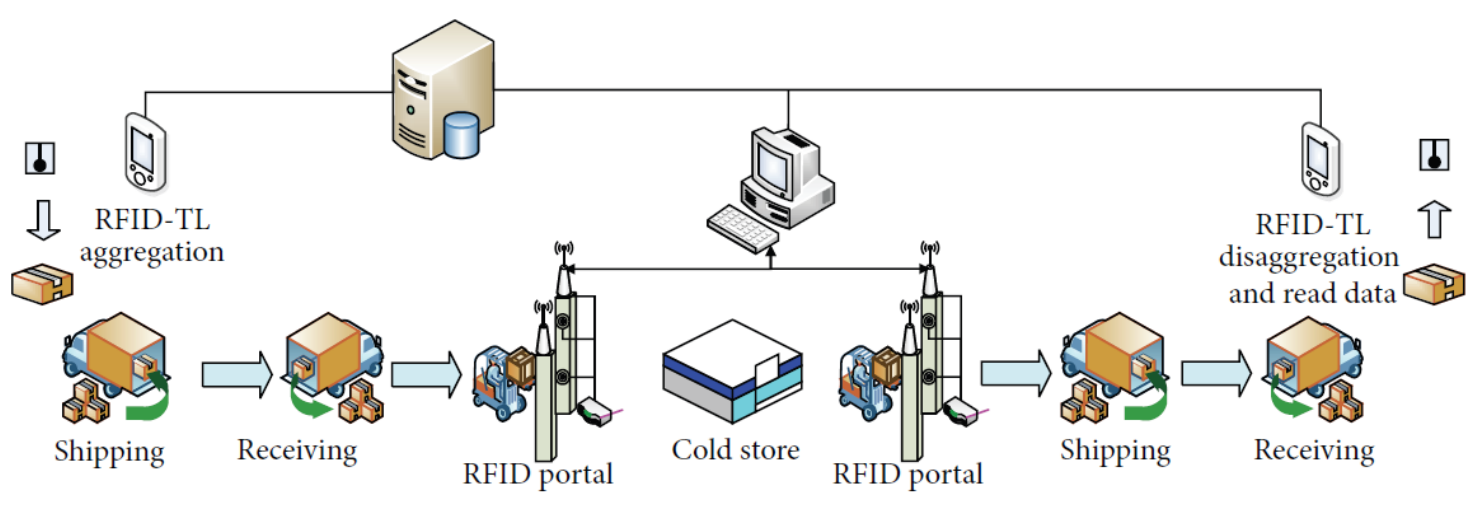

Figure 5.2 Logistical process for fresh fish (Trebar et al., 2013).

Kelepouris et al. (2007) introduces a centralized information system that all actors in the SC can access and upload data into, see Figure 5.3. In order to facilitate this actors have to have an RFID reader installed in their facilities. This will enable traceability and observation data to be sent via an IP network, which is accessible through a web browser. This idea can be considered as a gateway system in the sense that data gathered during transportation cannot be seen in real-time, only when it arrives at the next SC actor with an RFID reader where the data is uploaded.

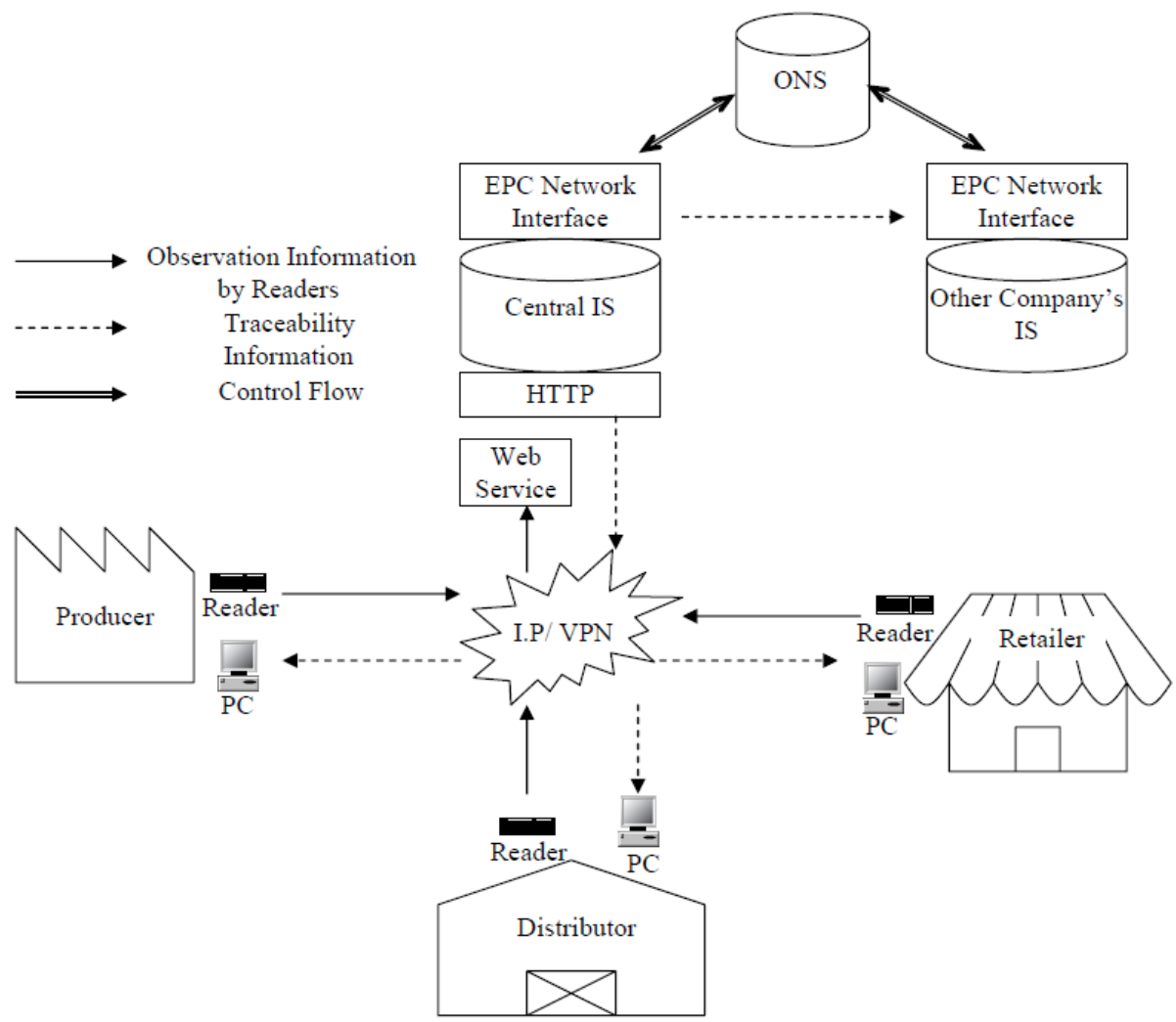

Figure 5.3 A central information service proposed by Kelepouris et al. (2007). 
One way to improve the gateway system is to introduce the concept of Critical Tracking Events (CTEs) as defined by Hickey and Bhatt (2013) where the basic CTEs are identified as:

- Receiving: Accepting a shipment from another facility

- Transformation: Anytime a product is modified either in packaging or composition

- Shipping: All items shipped

- Depletion: All items sold or consumed to produce an item to be sold for consumption

- Disposal: Products scrapped or destroyed making it unfit for consumption

At each CTE a few key data elements are defined, they can be mandatory/statutory, recommended and optional, see Figure 5.4. These key data elements allow transparency regarding both internal and external traceability.

To adapt the CTEs concept to the needs of a cold SC using a gateway system a couple of suggestions for improvements have been identified. The CTEs of interest have been identified with red circles in Figure 5.4. By adding temperature and location data to the data collected at these events, the procedure would be more suitable for a cold SC. These suggestions would enable data collection on temperature history, current location and identify critical tracking points in the SC. In addition to these modifications, a central information system could be used to keep track, store data and share relevant data with other actors in the SC. 


\begin{tabular}{|c|c|c|c|c|c|c|c|c|c|c|}
\hline \multirow{2}{*}{\multicolumn{2}{|c|}{$\begin{array}{l}\text { Statutory } \\
\text { Recommended } \\
\text { Standard }\end{array}$}} & \multicolumn{9}{|c|}{ Elements pertaining to track and trace in current regulations including the Reportable Food Registry } \\
\hline & & \multicolumn{9}{|c|}{$\begin{array}{l}\text { Elements that were determined to be necessary to fully track and trace product not currently required by } \\
\text { regulation }\end{array}$} \\
\hline \multicolumn{2}{|c|}{ Optional } & \multicolumn{9}{|c|}{$\begin{array}{l}\text { Elements that were determined to be helpful or show return to some business processes to fully track } \\
\text { and trace oroduct }\end{array}$} \\
\hline CTE & Receiv & Transformat & T1 & $\mathrm{T} 2$ & Shinning & & $\mathrm{D} 1$ & D2 & D3 & Disposal \\
\hline$\frac{\text { Descripti }}{\text { en }}$ & $\begin{array}{l}\text { Accept } \\
\text { ing a } \\
\text { shipm } \\
\text { ent } \\
\text { from } \\
\text { anoth } \\
\text { er } \\
\text { facility }\end{array}$ & $\begin{array}{l}\text { Changing the } \\
\text { identity or } \\
\text { characteristi } \\
\mathrm{cs} \text { of a } \\
\text { product }\end{array}$ & $\begin{array}{l}\text { Items } \\
\text { input } \\
\text { into a } \\
\text { transfor } \\
\text { mation } \\
\text { process }\end{array}$ & $\begin{array}{l}\text { Items } \\
\text { output } \\
\text { from a } \\
\text { transfor } \\
\text { mation } \\
\text { process }\end{array}$ & $\begin{array}{l}\text { Releasin } \\
\quad \mathrm{g} \\
\text { product } \\
\text { from one } \\
\text { facility to } \\
\text { another }\end{array}$ & $\begin{array}{l}\text { Product } \\
\text { removed } \\
\text { from the } \\
\text { supply } \\
\text { chain for } \\
\text { consumpt } \\
\text { ion }\end{array}$ & $\begin{array}{l}\text { Prod } \\
\text { uct } \\
\text { sold } \\
\text { direc } \\
t \text { to } \\
\text { cust } \\
\text { ome } \\
r\end{array}$ & $\begin{array}{l}\text { Beginnin } \\
\mathrm{g} \text { of } \\
\text { consump } \\
\text { tion for } \\
\text { consume } \\
\mathrm{r} \text { sale }\end{array}$ & $\begin{array}{l}\text { End of } \\
\text { consump } \\
\text { tion for } \\
\text { consume } \\
r \text { sale }\end{array}$ & $\begin{array}{l}\text { Product } \\
\text { scrapped } \\
\text { or } \\
\text { destroye } \\
\text { d making } \\
\text { it unfit } \\
\text { for } \\
\text { consump } \\
\text { tion }\end{array}$ \\
\hline Date & $\mathrm{x}$ & & $\mathrm{X}$ & $\mathrm{x}$ & $\mathrm{x}$ & & $\mathrm{x}$ & $\mathrm{x}$ & $\mathrm{x}$ & $\mathrm{x}$ \\
\hline Time & $\bar{x}$ & & $\mathrm{X}$ & $\bar{x}$ & $\mathrm{x}$ & & $\mathrm{x}$ & $\mathrm{x}$ & $\bar{x}$ & $\mathrm{x}$ \\
\hline$\frac{\text { Source }}{\text { Party }}$ & $x$ & & $\bar{x}$ & & $x$ & & & & & $x$ \\
\hline$\frac{\text { Target }}{\text { Party }}$ & $\mathrm{x}$ & & & $\mathrm{x}$ & $\mathrm{x}$ & & $x$ & $x$ & $x$ & $x$ \\
\hline Item & $\mathrm{x}$ & & $\mathrm{x}$ & $\mathrm{x}$ & $\mathrm{x}$ & & $\mathrm{x}$ & $\mathrm{x}$ & $\mathrm{x}$ & $\mathrm{x}$ \\
\hline $\begin{array}{c}\text { Let } \\
\frac{\text { Batch/s }}{\text { erial }} \\
\text { Number }\end{array}$ & $x$ & & $x$ & $\mathrm{x}$ & $\mathrm{x}$ & & $\mathrm{x}$ & $\mathrm{x}$ & $x$ & $\mathrm{x}$ \\
\hline Quantity & $\mathrm{x}$ & & $\mathrm{x}$ & $x$ & $\mathrm{x}$ & & $x$ & $x$ & $x$ & $x$ \\
\hline Unit of & $\bar{x}$ & & $\bar{x}$ & $\bar{x}$ & $\bar{x}$ & & $\bar{x}$ & $\bar{x}$ & $\bar{x}$ & $\bar{x}$ \\
\hline Order & $\mathrm{x}$ & & $\mathrm{x}$ & $\mathrm{x}$ & $\mathrm{x}$ & & & & & \\
\hline Order & $\mathrm{x}$ & & $\mathrm{x}$ & $\mathrm{x}$ & $\mathrm{x}$ & & & & & \\
\hline Iransfer & $\mathrm{x}$ & & & & $\mathrm{x}$ & & & & & \\
\hline $\begin{array}{l}\text { Iransfer } \\
\text { Type }\end{array}$ & $\mathrm{x}$ & & & & $\mathrm{x}$ & & & & & \\
\hline $\begin{array}{c}\frac{\text { Lot }}{\text { /Batch }} \\
\text { Relevant } \\
\text { Date }\end{array}$ & $\mathbf{x}$ & & $\mathbf{x}$ & $\mathbf{x}$ & $\mathbf{x}$ & & $\mathbf{x}$ & $\mathbf{x}$ & $\mathbf{x}$ & $\mathbf{x}$ \\
\hline$\frac{\text { Carrier }}{\text { ID }}$ & $\mathbf{x}$ & & & & $\mathbf{x}$ & & & & & \\
\hline Irafler \# & $\mathbf{x}$ & & & & $\mathbf{x}$ & & & & & \\
\hline Pallet ID & $\mathbf{x}$ & & $\mathbf{x}$ & $x$ & $\bar{x}$ & & & & & $\mathbf{x}$ \\
\hline
\end{tabular}

Figure 5.4 Traceability guidance table showing CTEs and key data elements adapted from Hickey and Bhatt (2013).

\subsubsection{Real-Time}

Identification technologies falling under this category are: RFID and WSN. Real-Time can offer real-time communication on top of real-time environmental data and traceability. This offers the user the opportunity to access data (e.g. temperature and location) in real-time. Which in turn can be used to trigger temperature alerts when/if temperatures are out of the set range allowing the user to react quickly and evade unplanned product losses. It also guarantees the best possible quality and safety of the products. 
Providing this real-time communication option is not an easy task. In a pilot study conducted by Abad et al. (2009) they developed both a flexible and rigid HF semi-passive RFID tag that could record light, temperature and humidity. A commercial reader was used to process the information gathered and transmitted it via USB cable to a computer. The tags could be programmed to read data at certain intervals, seconds or minutes, and likewise the reader could gather the data that at certain intervals. Their study therefore provided real-time temperature and traceability information at any point in the cold chain of fresh fish, leading to real-time communication application in the SC. However, they do not mention whether the RFID tags could be used to send out the current location by means of GPS or activate temperature alerts.

Chen et al. (2014) made a passive RFID sensor tag that had a special mobile code and identification code. This special mobile code could inform the reader what kind of storing conditions the goods needed. During transportation in a refrigerated truck, a reader checked if the temperature inside the truck was within the set temperature range for the product and if the temperature was too high/low it would decrease/increase it by one degree and check again. An information system stored all the sensing data sent by the reader. Furthermore, the reader could calculate the expiration dates of the goods and issue alarms if recalls were necessary. This kind of system minimizes communication to a user as the system responds on its own based on the information specified in the original mobile code. However, the system described by Chen et al. (2014) does not seem to provide real-time location.

In addition to the RFID technology, WSN applications have been used for real-time information gathering. Xiao et al. (2016) conducted a pilot study where they used WSN to monitor real-time temperature fluctuations in the cold chain of frozen fish. The WSN monitoring system consisted of three layers; a wireless temperature sensing node, aggregation node and a management system, see Figure 5.5. Xiao et al. (2016) used the ZigBee protocol, for details see Chapter 4.7. Temperature sensors were put in each box of frozen fish sending data at regular intervals and going to sleep after sending. The aggregation nodes send sampled data to the management system via GPRS, which stores the data and communicates the real-time data and shelf-life predictions in the user interface. In their pilot study, only the transportation scenario was investigated and the aggregation node was placed in the driver's cabin. The system did not send any alarms since no upper or lower limits were set for the temperature and real-time location was not provided only logistic traceability. 


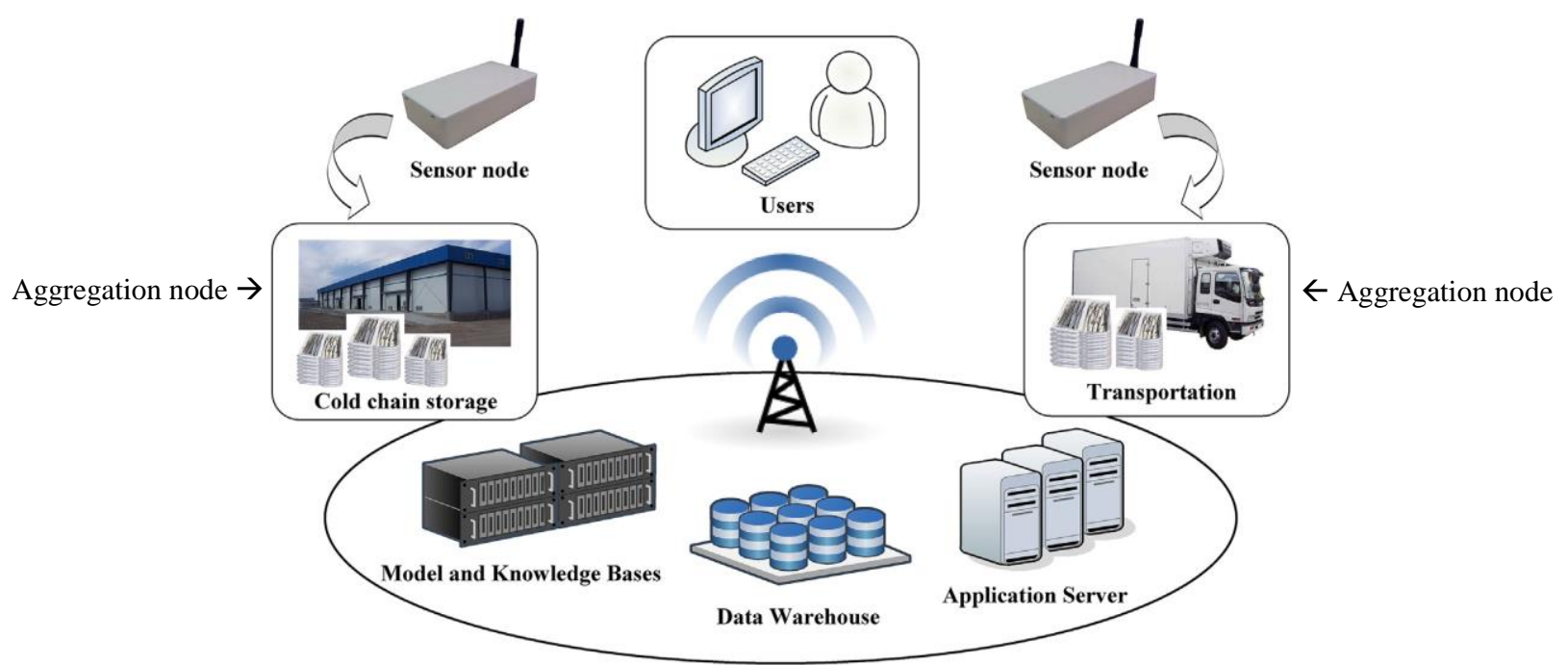

Figure 5.5 A WSN architecture adapted from Xiao et al. (2016).

Wang et al. (2015) also used the WSN technology to monitor real-time environmental condition in the SC of fresh peaches. Data collected included environmental conditions per container, the state of motion and vehicle location, which was logged and accessible to users online. The location of the vehicle was detected using GPS. In this study, temperature alarms where not triggered but e.g. abnormal motion and illegal opening of containers where detected. This type of information can be helpful to verify claims concerning safety and security (Ruiz-Garcia et al., 2010).

Other researchers have combined RFID and WSN applications in order to create an intelligent tracking system. Luo et al. (2016) proposed an intelligent tracking system utilizing WSN sensor nodes, a RFID system and GPS. The RFID tags handle the collection of the logistical information while the WSN system measures temperature in cold storage units and in refrigerated trucks, the data collected is sent to routers that transmit it onwards to a remote monitoring center where it is processed and stored. If anything about the status of the products is abnormal alerts are generated so immediate actions can be taken. Trucks have GPS installed to be able to see the past and present location of the products. However, as the system can only provide real-time temperature in the trucks or cold storages a whole SC overview is not achieved. 


\section{Construction of the Decision Support Framework}

The first step in the construction of the decision support framework was to compile all the functions and attributes mentioned in Chapter 4 and define a uniform terminology for them. The definitions were expressed in the form of questions for all the functions/attributes listed in Table 6.1.

Table 6.1 Relative functions/attributes and definitions.

\begin{tabular}{ll}
\hline Function/Attribute & Definition \\
\hline Economical & Is the technology economical? \\
Automatic ID & Does the technology provide automatic identification? \\
Frequency & What frequency range does the technology work on? \\
Lifetime & What is the lifetime of the technology? \\
Line of sight & Does the technology require line of sight to work? \\
Memory & Is the technology able to store large amount of different data, \\
& that is does it have a large or small memory? \\
Cooperation among tags & Does the technology provide a cooperation among tags? \\
Printable / Flexible & Is the technology printable and flexible at the same time? \\
Environmental & Is the technology protected against environmental conditions \\
conditions & such as cold, salt and humidity? \\
Reading range & What is the reading range, in metrics, of the technology? \\
Real-time alerts & Does the technology provide real-time alerts? \\
Real-time & Does the technology provide real-time communication? \\
communication & \\
Real-time location & Does the technology provide real-time location? \\
Real-time temperature & Does the technology provide real-time temperature? \\
Security & What is the level of security provided? \\
Size & Is the technology larger or smaller than a regular credit card? \\
Uniform standards & Are uniform standards used around the world for the \\
& technology? \\
Value of product & What is the value of the products? Does it provide high or low \\
& income?
\end{tabular}

The next step was to answer the questions prepared in Table 6.1 for the different categories of technologies identified in Chapter 4, see Table 6.2. For simplicity, it was decided to group together paper records, alphanumerical codes and holograms as they all have similar trades, likewise active and semi-passive RFID were grouped together (see Table 6.2). The literature review in Chapter 4 was mainly used to answer the questions raised in Table 6.1. If the literature did not specifically mention some of the functions, e.g. in the case of barcodes, whether they are printable or not, the author used her own intuition to answer the question raised, these answers are indicated with red text in Table 6.2. If a function/attribute did not apply to a specific category this was indicated with Not Applicable (NA) in the table. 
Table 6.2 Traceability functions/attributes and technologies overview.

\begin{tabular}{|c|c|c|c|c|c|c|}
\hline \multirow[b]{3}{*}{ Function/Attribute } & \multicolumn{3}{|c|}{ Static traceability } & \multicolumn{3}{|c|}{ Dynamic traceability } \\
\hline & \multicolumn{2}{|c|}{ No sensing } & \multirow{2}{*}{$\begin{array}{c}\text { Sensing } \\
\begin{array}{c}\text { Intelligent packaging } \\
\text { with TTI }\end{array}\end{array}$} & \multirow{2}{*}{$\begin{array}{l}\text { No sensing } \\
\text { RFID passive }\end{array}$} & \multicolumn{2}{|c|}{ Sensing } \\
\hline & $\begin{array}{c}\text { Paper records, } \\
\text { alphanumerical codes } \\
\text { and holograms } \\
\end{array}$ & Barcodes & & & $\begin{array}{l}\text { RFID active / } \\
\text { semi-passive }\end{array}$ & WSN system \\
\hline Automatic identification & NA & Yes & NA & Yes & Yes & No \\
\hline Cooperation among tags & NA & NA & NA & No & No & Yes \\
\hline Economical & Yes & Yes & Yes & Yes & No & No \\
\hline Frequency & NA & NA & NA & All frequencies & $>433 \mathrm{MHz}$ & $>865.5 \mathrm{MHz}$ \\
\hline Lifetime & NA & NA & NA & Unlimited & Depends on battery & Depends on battery \\
\hline Line of sight & Yes & Yes & Yes & No & No & No \\
\hline Memory per tag & NA & Small & NA & Large & Large & Small \\
\hline Printable / Flexible & Yes & Yes & Yes & Yes & No & No \\
\hline Environmental conditions & No & Yes & Yes & Yes & No & No \\
\hline Reading range & NA & $2 \mathrm{~m}<$ & NA & $3 m<$ & $100 \mathrm{~m}<$ & More than RFID \\
\hline Real-time alerts & No & No & Yes & No & Yes & Yes \\
\hline Real-time communication & No & No & No & Yes & Yes & Yes \\
\hline Real-time location & No & No & No & No & Yes & Yes \\
\hline Real-time temperature & No & No & Yes & No & Yes & Yes \\
\hline Security & Low & Low & NA & Low & Low & High \\
\hline Size & Small & Small & Small & Small & Large & Large \\
\hline Uniform standards & No & Yes & No & No & No & Yes \\
\hline Value of product & Low & Low & High & High & High & High \\
\hline
\end{tabular}


When these steps had been carried out, a decision-tree was constructed based on the knowledge gathered during the course of this study. The decision-tree will lead the user through different actions in order to identify the most suitable traceability technology. The decision-tree constructed can be seen in Figure 6.1, a question resulting in a "No" answer is indicted with red arrows, while a question resulting in a "Yes" answer is indicated with green arrows in order to support the user in the decision making process. The decision-tree was broken down into seven figures, Figure 6.2 to Figure 6.8, to better illustrate and discuss the decision-tree process.

The first question in the decision-tree, Figure 6.2, determines whether the product requires temperature sensors or not, based on whether the product is perishable. To make sure that the perishable product truly requires temperature sensing in a cold chain application the next question is raised to determines whether this is the case, since not all perishable products require temperature monitoring. The next step is to determine the value of the product to see if the investment can be high or low.

For perishable high value products that require temperature monitoring, the next question would be related to how sensitive the product is to temperature change. This is done to determine the complexity and what level of monitoring is needed, as very sensitive products require more monitoring in form of communication to the user. If the sensitive products requires real-time communication throughout the whole SC a Real-Time system is needed if not a Gateway system if sufficient. To determine what kind of Real-Time technology should be used the user can choose between three different routes; Automatic identification, Sensitive information and Low error rate. Based on the route chosen a suitable technology for Real-Time can be determined.

However, for perishable low value products that require temperature monitoring the next question would determine whether temperature data received at the end of the SC is sufficient. If this is the case, the user can choose between two routes a visual interpretation or a computer-based system. However, if data received at the end of the SC is not sufficient the user would have to use a technology required for high value items.

For non-perishable or perishable products that do not require temperature monitoring a question regarding whether the product is valuable is raised. If it is a high value product a more advanced technology (passive RFID) is suggested, while a low value product that does not need automatic identification would use a less expensive option. If the low value products require an automatic system e.g. due to product volume, the user would choose between two routes; More volume and Less volume. Products that are shipped in large volumes would e.g. benefit from using a type of technology that minimizes human labor if it is labeled on an item level.

The next steps in the decision-tree are used to further identify the needs of the user and to make a final choice regarding the selection of the identification technology required, these selection processes are shown in Figure 6.3 to Figure 6.8. 


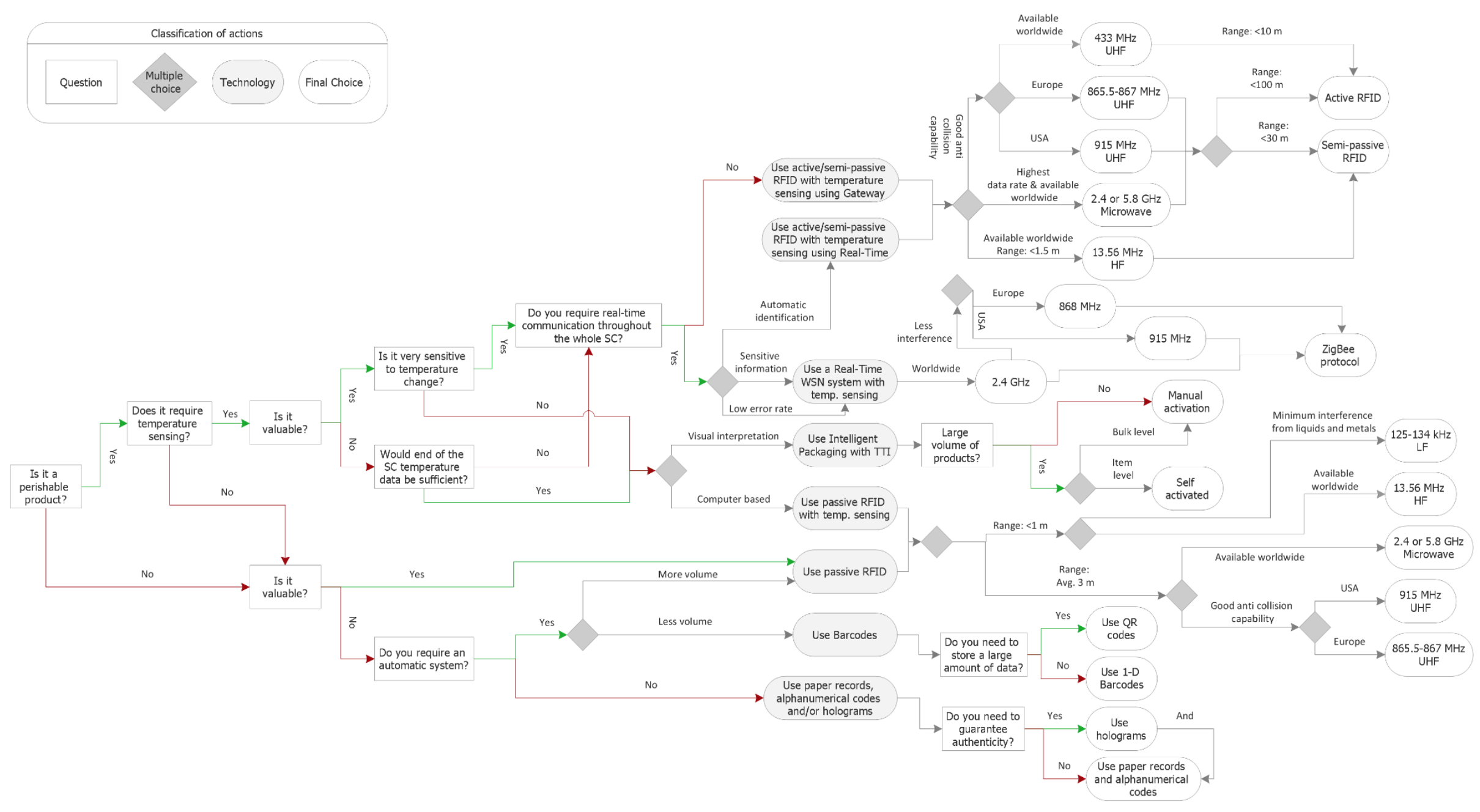

Figure 6.1 Illustration of the whole decision-tree for a cold chain traceability application. 


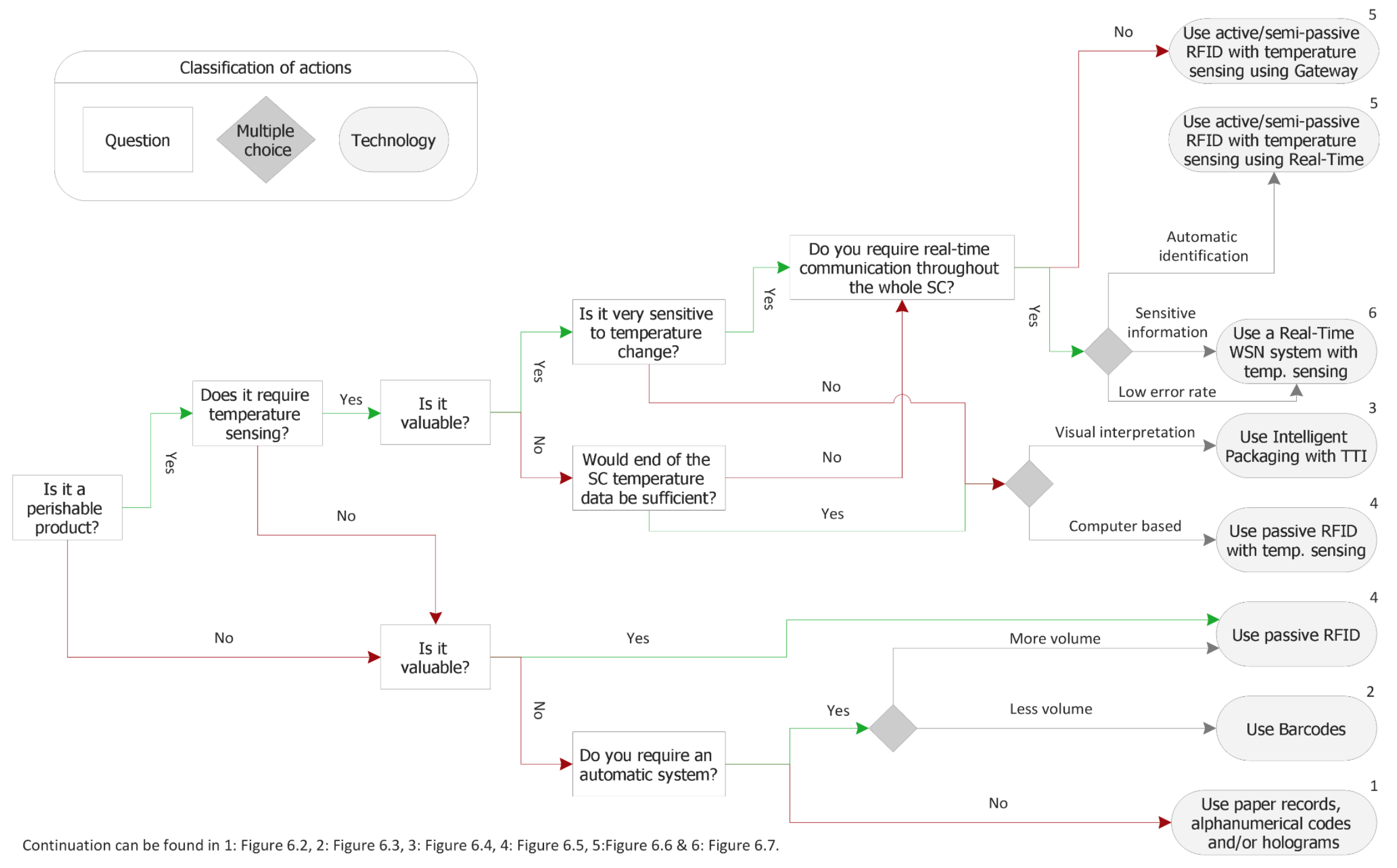

Figure 6.2 Decision-tree for a cold chain traceability application, choosing a suitable traceability technology system. 
If the decision-tree in Figure 6.2 indicates that the user should use paper based, alphanumerical codes and/or holograms for his traceability system. He is referred to Figure 6.3 where he can further specify his needs to guarantee the authenticity of the product. If he does not have to guarantee the authenticity, then he can only use paper records and alphanumerical codes. However, if authenticity it crucial the user should also use holograms. Users that find out that they should use barcodes according to Figure 6.2 are referred to Figure 6.4 where the amount of the data stored on the label determines the final choice of barcode type. On the other hand, if the decision-tree indicates that the user should use intelligent packaging (IP) with TTI the user should consult Figure 6.5, which determines what kind of IP activation is required based on the volume of the products.

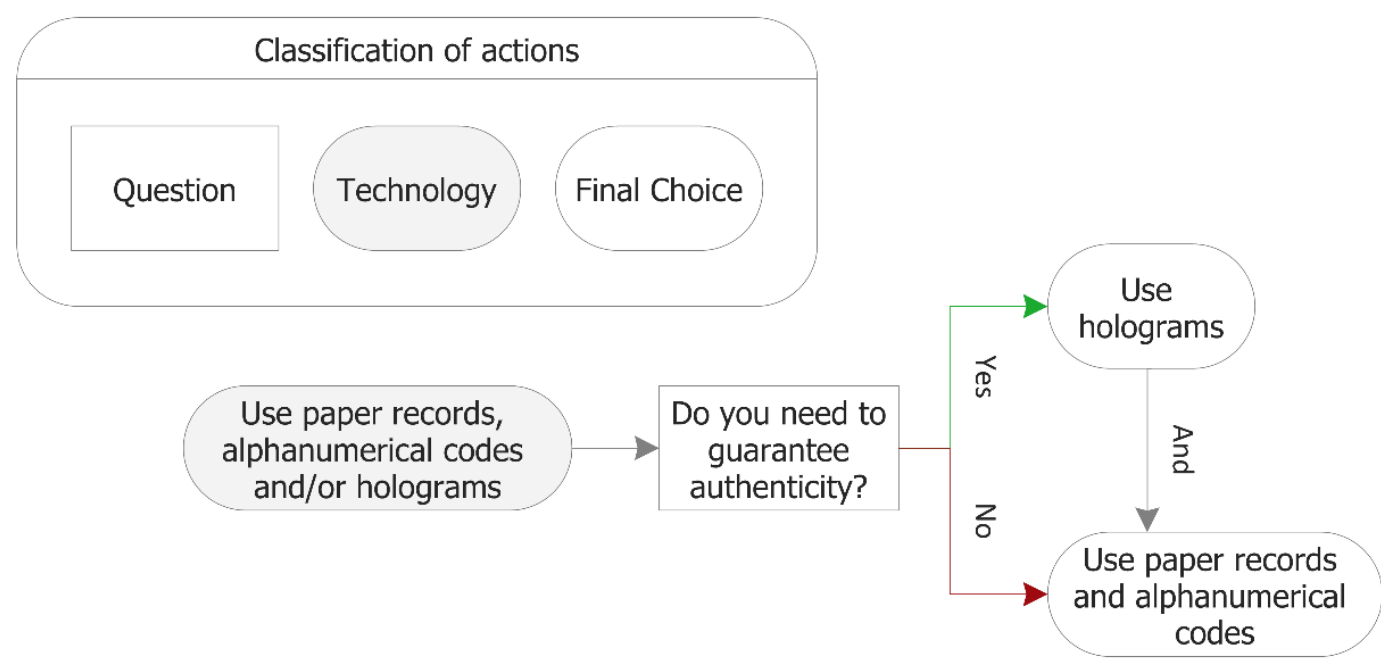

Figure 6.3 Final selection process when using paper records, alphanumerical codes and/or holograms.

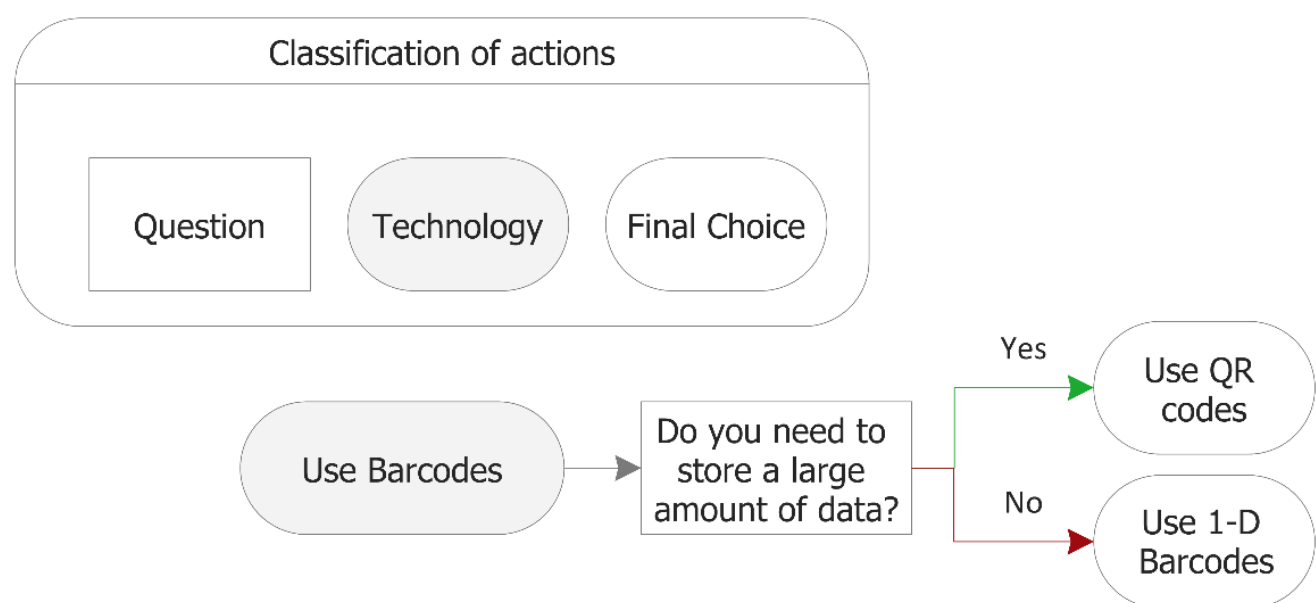

Figure 6.4 Final selection process when using barcodes. 


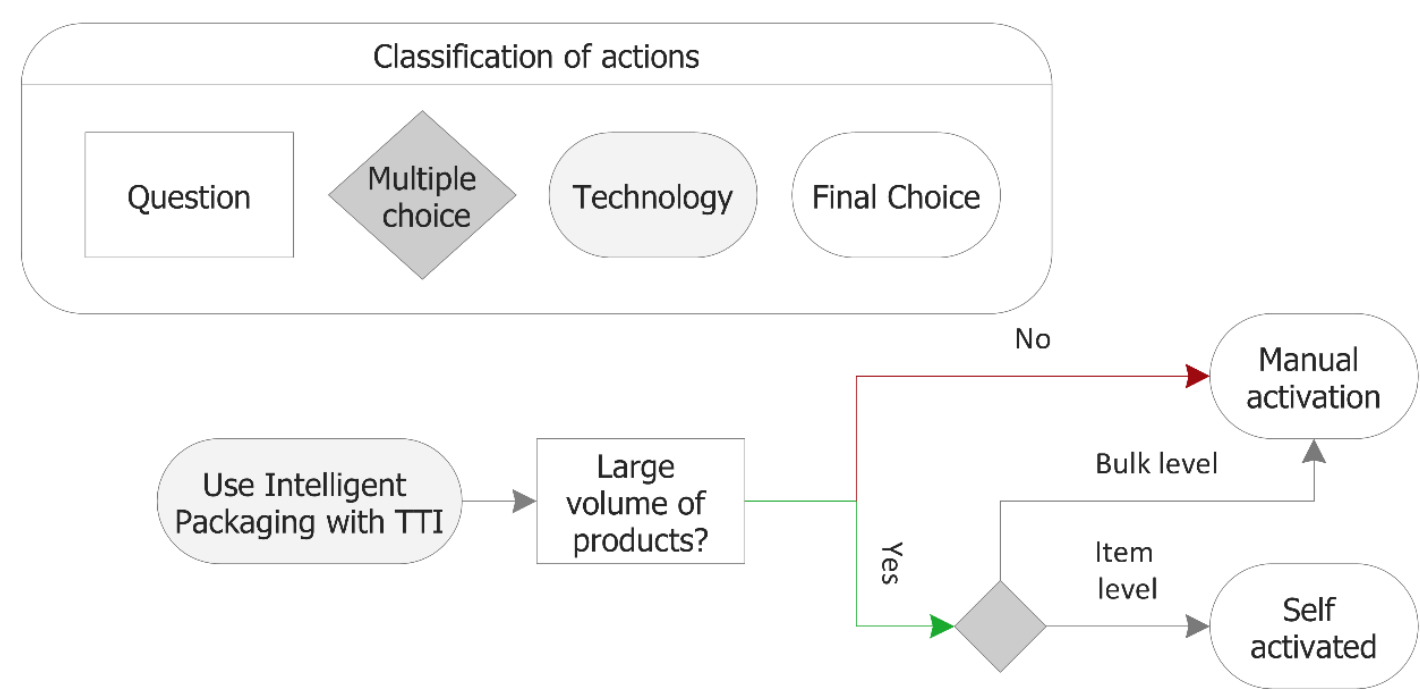

Figure 6.5 Final selection process when using intelligent packaging with TTI.

Users that learn they should either use passive RFIDs or passive RFIDs with temperature sensing are referred to Figure 6.6, where the type of the passive RFID is further analyzed. Since RFIDs work on different frequency levels the right kind of frequency for the user needs to be determined. In order to accomplish this the user first has to choose the reading range of the tag. Tags having a range smaller than one meter can either be available worldwide or have a minimum interference from liquids and metals. Tags with an average range of three meters can either be used worldwide or have a good anti-collision capability, but then the frequency band options differ between Europe or USA.

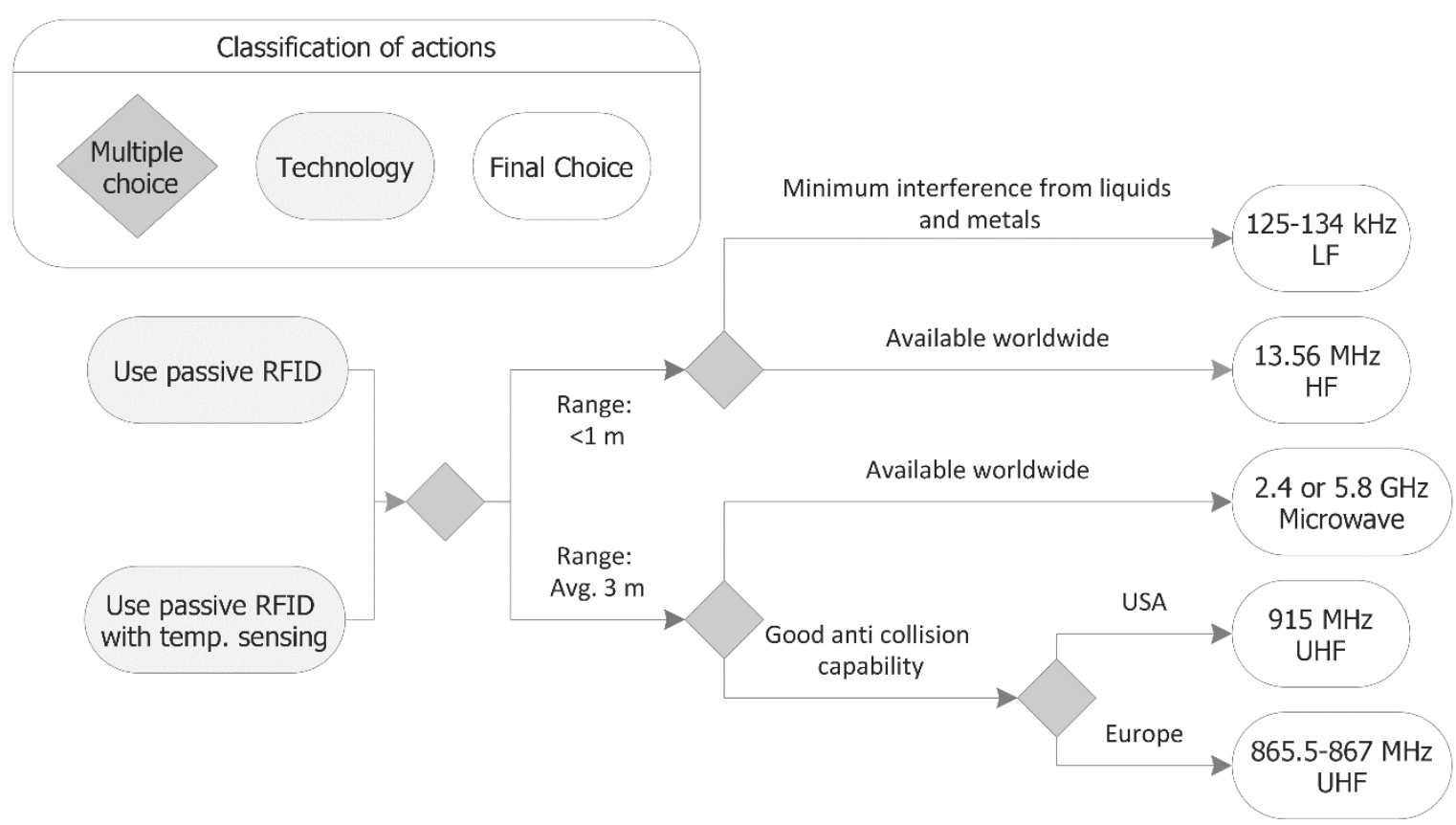

Figure 6.6 Final selection process when using passive RFIDs. 
In a similar way, users that require active/semi-passive RFIDs with temperature sensing using a Gateway or Real-Time system are referred to Figure 6.7. It determines the frequency band required for these options and then depending on the range what type of RFID tag they will end up with as their final choice, see Figure 6.7.

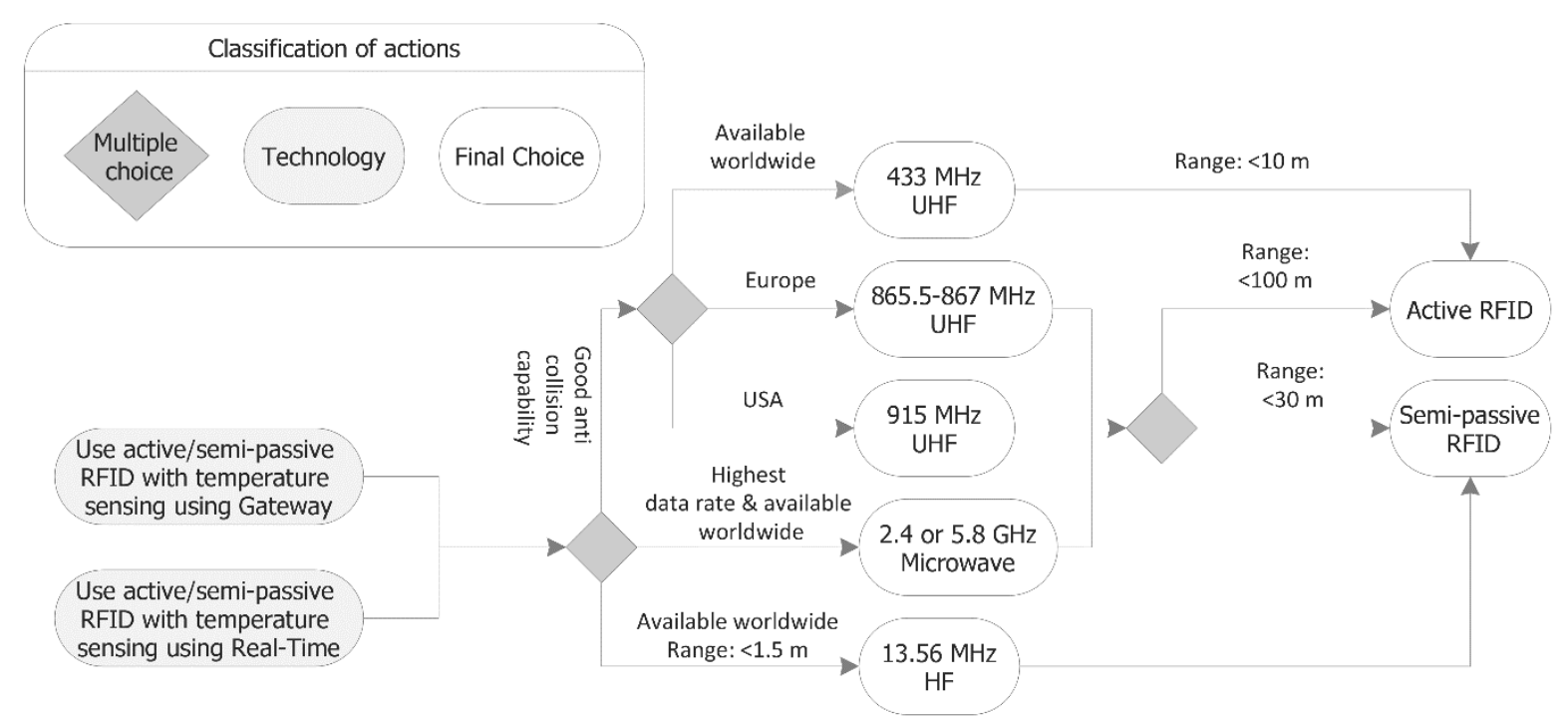

Figure 6.7 Final selection process when using active or semi-passive RFIDs.

Finally, Figure 6.8 is for users that need a WSN system as their traceability technology. In this case, the user starts with a frequency band that works worldwide but if he wants a band that has less interference he must choose between different options for Europe or USA. However, all the frequencies bands for the WSN system use ZigBee as their protocol.

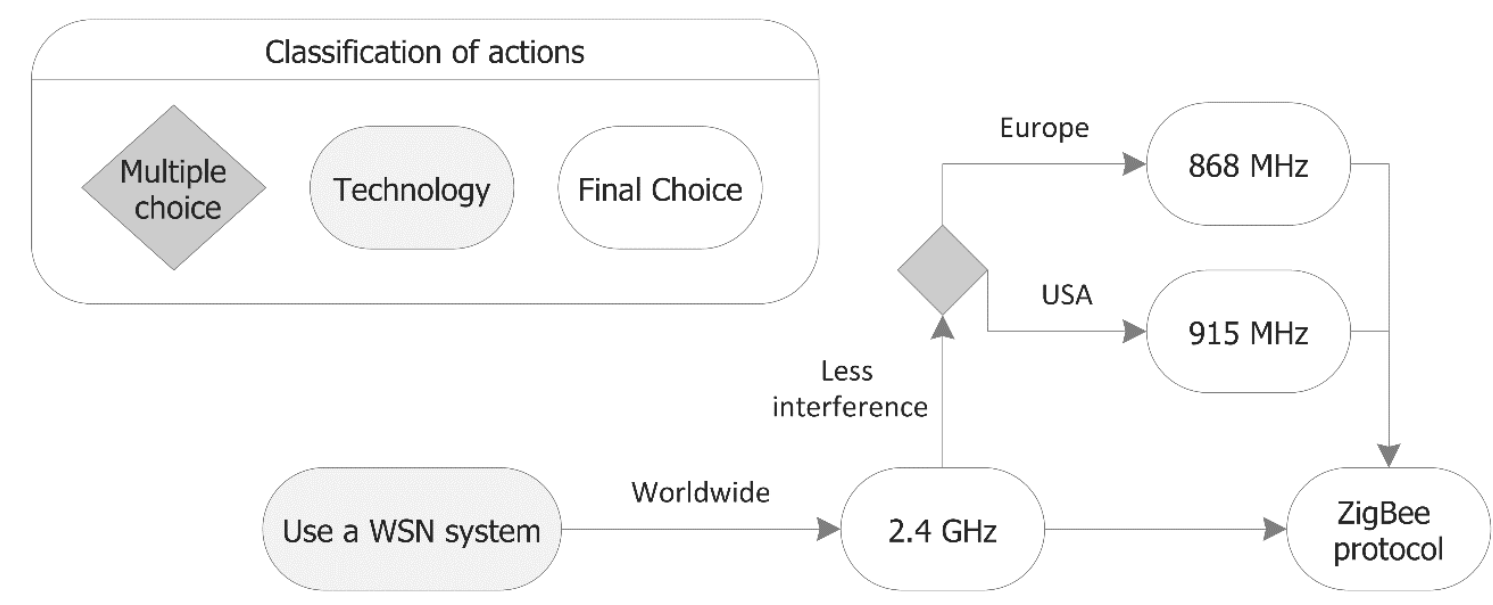

Figure 6.8 Final selection process when using a WSN system. 


\section{Field Trip}

During the course of this study a three-day field trip to a collaborative partner, Oulu University of Applied Science, in the Smart-Fish project was carried out. The aim of the Smart-Fish project is to develop a new type of cold chain Smart-Label that will be flexible and printable, can sense temperature, time and location, provide real-time data to a user throughout the whole SC at any point, send real-time alerts, be affordable and accessible via an online database. The aim of the field trip was to get an overview of the current state of technologies that are being developed for the Smart-Fish project.

The researcher prepared a list of questions that he wanted to ask the collaborators during the stay in Oulu, this list can be found in Table 0.1 in the Appendix. The questions were based on different functions that the researcher identified during the literature review. The answers to these questions were intendent to aid the researcher in making a decision-tree and to better comprehend this research field.

During the first day at Oulu's University of Applied Science, the researcher obtained a comprehensive introduction to printable technologies. At the university, they have a laboratory called PrinLab, which specializes in printable electronics. The purpose of the laboratory is to introduce and develop different printing techniques and applications (OMAK, 2017). The researcher was introduced to different kinds of equipment that is applied during the process and learned what difficulties can arise. In the case of printable sensors, the material used and printed on plays a big role as it must be strong enough to prevent tearing. It must also provide a good surface structure so that the printed sensor can be kept intact and be protected with the use of an insulating layer. The importance of this is shown in Figure 7.1, in this case little bubbles have emerged in the sensor due to the inappropriate surface material making the sensor more vulnerable to fractions affecting its functionality and vulnerability to environmental conditions such as water. The advantages of this kind of printed technology are that it is possible to print the sensor directly onto the packaging material of the products and it can also be easily mass produced.

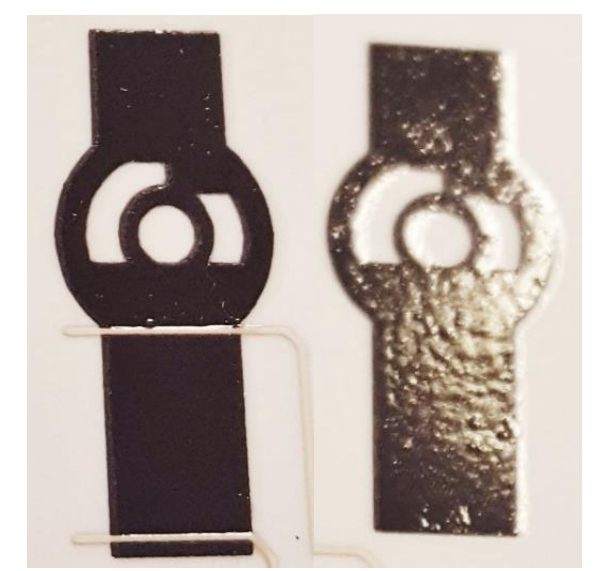

Figure 7.1 Printable electronic tags an illustration of fractions and surface roughness due to the material of the printed surface. 
As the university is working on developing a prototype of the Smart-Label both the second and third day were dedicated to learning more about the current state of the developmental process and ask the prepared questions. A few selected functions and their answers from Table 0.1 in the Appendix can be seen in Table 7.1. It was interesting to obtain their answers, as it required them to think of why the developmental process and decision made. Where they all informed decisions or only based on intuition?

Table 7.1 Demonstration of answers gathered at Oulu University of Applied Science, adopted from Appendix

\begin{tabular}{|c|c|}
\hline Function & Answer \\
\hline Range & Their target is around 20 meters, the length of the longest containers \\
\hline $\begin{array}{l}\text { Real-time } \\
\text { communication }\end{array}$ & Through a router it will be able to send data in real-time \\
\hline Battery life & Aiming for 96 hours \\
\hline Alerts & $\begin{array}{l}\text { Will send a message when temperature goes out of range, right now } \\
\text { the user would be able to see it online through their webpage }\end{array}$ \\
\hline Transportation & Right now, only focusing on road transportation between actors \\
\hline
\end{tabular}

The current prototype of the Smart-Label is not printable as they are still trying to figure out how to use a printable battery that can last the required 96 hours that they are aiming for, see Table 7.1. To achieve this, it is important to lower the power consumption of the label. Currently they are also working on optimizing a printed temperature sensor, as it is very sensitive and therefore hard to obtain accurate temperature measurements. They have achieved real-time communication through the use of a router that gathers both temperature data and the location of the tag via GPS. The router sends the data on to a computer system and the user can log in to a website or a smartphone application to see the status of his products. The temperature history is illustrated both with tables and graphs while the location history can be displayed on a geographical map.

Right now, they are testing different open source technologies that utilities standardized protocols to investigate what will be appropriate for the Smart-Label. They have tested a combination of Raspberry Pi3 and XBee (that uses ZigBee) technologies and their next step is to test Thread and 6LoWPAN as it uses low power and mesh networking. Hence, they are focusing on WSN applications and not RFID.

The literature research carried out did not indicate any current solution that can achieve the overall aim of the Smart-Label. That is provide a real-time communication along the whole SC that indicates temperature, time and location data, triggers alerts and can be used for tracking. This shows a gap in the market making this new Smart-Label a much-needed option for real-time traceability from "farm to fork". 


\section{Discussion}

Managing a cold supply chain is not an easy task as perishable products can easily become spoiled if a certain storage conditions e.g. temperature, humidity, light are not maintained throughout the SC. This can lead to a loss of sales, cause safety hazards, increase waste and can damage a company's reputation. In order to prevent this businesses can invest in quality and safety measures that enable monitoring of important storage conditions. The factor that has the most impact on spoilage of perishable products is temperature change over a period of time. Therefore, investments in temperature monitoring can lead to longer shelf-life, as well as increased quality and safety.

In this study, a decision support framework was constructed which consists of a table (Table 6.2) and a decision-tree (Figure 6.1). This framework will support the user in the decision making process regarding suitable traceability technologies for their products. Expected users of the framework are e.g. Supply Chain Managers in larger businesses and CEO's in small and medium-sized businesses that are trying to identify a suitable traceability system for their products. Other possible users could be e.g. developers of traceability technologies. They would use the decision support framework to investigate existing technologies and what solutions are required for different products.

In the decision-tree (Figure 6.1) one of the key questions is related to the value of the products. This might not be the right terminology in all cases e.g. a low value product with a high turnover rate could benefit from using a more expensive tracking solution such as passive RFIDs. It can therefore be recommended that a cost-benefit analysis is included in the decision making process as this would result in more accurate information regarding the value of the technologies and what costs and benefits could be expected. This indicates that the framework can be developed further and that it is still in its early stages.

For high value perishable products the decision-tree in Figure 6.1 shows that WSN and RFID technologies are suitable for real-time applications. However, both these technologies are still in their early stages. For example, there is currently no solution available that can provide real-time communication along the whole SC and at the same time indicate temperature, alerts, location and other traditional traceability data. This shows the need for a tag providing these types of functions, which is exactly what the Smart-Fish project aims to develop. The main advantages of having this kind of electronical system is the visibility that it provides the users along the SC and that it is widely accessible via the internet. Further, the measurements obtained are consistent and provide valuable information regarding the conditions encountered both internally during processing and externally during transportation. This type of data would also provide an advantage in legal situations and during safety inspections.

The main disadvantages in many real-time systems today is that visible constant temperature monitoring is not carried out through the entire SC. The main focus has been on certain points in the chain, such as cold storages and refrigerated trucks. This leaves out vulnerable handover points where the products are taken out of the temperature controlled environments and are exposed to external temperatures. If there is no nearby reader at these handover 
points the gathered real-time data from the tags will be lost. If this would occur frequently over a longer period vital temperature data would be lost and the product owner would never be aware of this weakness of the system. This could be prevented if the tags could sense that no reader is nearby and an internal storage would then store the data until a reader would be in range.

In order to achieve a fully functional real-time system it vital that all actors in the SC, including transportation companies, take part in the implementation of a synchronized system as readers need to be installed in every facility and truck holding the products. This would result in a traceability system that could communicate with each actor, reduce duplication of work, eliminate data loss and provide transparency. In the long run this investment would also provide a more competitive edge and better reputation.

The main issue regarding real-time technologies such as RFID and WSN still the high implementation cost. However, it is expected that with further technological development the cost will reduce. In SCs where actors have close relationship and the chain is not very long re-usable tags could be used, this would further reduce the implementation cost. The lack of uniform global standards also hinders the implementation of RFIDs. This is because RFID readers cannot read tags of different frequencies. To solve this problem either the standards would have to be globalized or multiple frequency readers could be developed. Despite these challenges and limitations, real-time applications have the potential of being economically viable for certain businesses.

According to the literature review, most of the pilot studies focused on road transportation and not on e.g. train, sea or air transportation. This could be due to legislation related to air cargo or lack of technological feasibility. In train and sea transportation, one of the complications is related to lack of connectivity in real-time communications. This is because a sea container could be surrounded by other containers that weaken the signal strength, while tunnels could weaken the signal during train transportation. It should also be pointed out that the pilot studies did not send data every second to achieve a "perfect" real-time communication but rather every few minutes. On the other hand, the smaller the intervals are the more "real-time" the communication can be. This would result in massive amount of data gathering and post processing.

"Traceability" might not be the best term to be used in this study as the focus was on technologies used to track products downstream in the SC. That is why the term "trackability" might better suit this study but this term does to not exist in this field. The author would therefore like to propose the addition of this term or alternatively a new expression that captures "tracking" and "tracing" in a more logical manner.

\subsection{Future research}

The scope of this study is extensive and diverse and this is merely the beginning. There is a need for further research and the suggestions listed below could lead to further development in this field:

- Testing and validating the decision support framework presented here;

$\circ$ Is it extensive enough?

- Is there a lack of detail?

- Carry out a cost-benefit analysis of the different technologies; 
- A Multi-Criteria Decision Analysis could result in more accurate conclusions;

- A researcher with an electrical engineering background could compliment this study by investigating the technical advantages of the technologies to further distinguish their features;

- As the technical advancements are rapid the information and the decision support framework need to be updated regularly;

- Gather data regarding relevant cold SC from the medical and pharmaceutical field;

$\circ$ Are there different cold chain applications there?

- Carry out more pilot studies on train, sea and air transportation for real-time applications;

- Carry out a pilot study using the Smart-Label developed by Smart-Fish; 



\section{Conclusion}

The aim of this study was to provide an overview of current technical solutions in cold supply chains and to support the user in the decision-making process. The following research questions were defined: What kind of traceability solutions are available right now in the cold supply chain? Is it possible to develop a decision support framework for choosing a suitable traceability solution? The main findings were summarized in Chapters 3, 4, 5 and 6 . This section summarizes the main findings in order to answer the research questions.

1. What kind of traceability solutions are available right now in the cold supply chain?

A theoretical background regarding traceability and important elements in the cold supply chain is provided in Chapter 3. Different traceability technologies were identified in Chapter 4, they ranged from simple paper based solutions to highly automated systems. In Chapter 5 traceability structures where analyzed and two main traceability structures identified; static or dynamic traceability. These two different types of structures and their sub-structures where then analyzed further.

2. Is it possible to develop a decision support framework for choosing a suitable traceability solution?

The short answer is "Yes". A decision support framework was constructed, Chapter 6, that will help the user to identify what kind of traceability technology and structure best suits his products. This will result in a more informed decision making process. The framework consists of a table listing up functions and attributes of the different technologies and a decision-tree.

This study can be regarded as the beginning of a more extensive, diverse and detailed decision support framework to track products in the cold supply chain. It should therefore be developed further in order to meet the demanding requirements of its users. 



\section{References}

Abad, E., Palacio, F., Nuin, M., de Zarate, A. G., Juarros, A., Gomez, J. M., \& Marco, S. (2009). RFID smart tag for traceability and cold chain monitoring of foods: Demonstration in an intercontinental fresh fish logistic chain. Journal of Food Engineering, 93(4), 394-399. doi:10.1016/j.jfoodeng.2009.02.004

atlasRFIDstore. (2017). SMARTRAC R6 DOGBONE RFID WET INLAY (MONZA R6). Retrieved from https://www.atlasrfidstore.com/smartrac-r6-dogbone-rfid-wet-inlaymonza-r6/

Aung, M. M., \& Chang, Y. S. (2014). Traceability in a food supply chain: Safety and quality perspectives. Food Control, 39, 172-184. doi:10.1016/j.foodcont.2013.11.007

Badia-Melis, R., Mishra, P., \& Ruiz-Garcia, L. (2015). Food traceability: New trends and recent advances. A review. Food Control, 57, 393-401. doi:10.1016/j.foodcont.2015.05.005

Badia-Melis, R., Qian, J. P., Fan, B. L., Hoyos-Echevarria, P., Ruiz-Garcia, L., \& Yang, X. T. (2016). Artificial Neural Networks and Thermal Image for Temperature Prediction in Apples. Food and Bioprocess Technology, 9(7), 1089-1099. doi:10.1007/s11947-016-1700-7

Bertolini, M., Bevilacqua, M., \& Massini, R. (2006). FMECA approach to product traceability in the food industry. Food Control, 17(2), 137-145. doi:10.1016/j.foodcont.2004.09.013

Bhatt, T., Buckley, G., McEntire, J. C., Lothian, P., Sterling, B., \& Hickey, C. (2013). Making Traceability Work across the Entire Food Supply Chain. Journal of Food Science, 78, B21-B27. doi:10.1111/1750-3841.12278

Bosona, T., \& Gebresenbet, G. (2013). Food traceability as an integral part of logistics management in food and agricultural supply chain. Food Control, 33(1), 32-48. doi:10.1016/j.foodcont.2013.02.004

Chen, Y. Y., Wang, Y. J., \& Jan, J. K. (2014). A novel deployment of smart cold chain system using 2G-RFID-Sys. Journal of Food Engineering, 141, 113-121. doi:10.1016/j.jfoodeng.2014.05.014

Chrysochou, P., Chryssochoidis, G., \& Kehagia, O. (2009). Traceability information carriers. The technology backgrounds and consumers' perceptions of the technological solutions. Appetite, 53(3), 322-331. doi:10.1016/j.appet.2009.07.011

Codex Alimentarius Commission. (2015). Codex procedural manual. Twenty-third edition. Retrieved from ftp://ftp.fao.org/codex/Publications/ProcManuals/Manual_23e.pdf 
Costa, C., Antonucci, F., Pallottino, F., Aguzzi, J., Sarria, D., \& Menesatti, P. (2013). A Review on Agri-food Supply Chain Traceability by Means of RFID Technology. Food and Bioprocess Technology, 6(2), 353-366. doi:10.1007/s11947-012-0958-7

CSCMP. (2013). CSCMP Supply Chain Management Definitions and Glossary. Supply Chain Management Terms and Glossary. Retrieved from http://cscmp.org/CSCMP/Educate/SCM_Definitions_and_Glossary_of_Terms/CSC MP/Educate/SCM_Definitions_and_Glossary_of_Terms.aspx?hkey $=60879588$ $\underline{\text { f65f-4ab5-8c4b-6878815ef921 }}$

Cuinas, I., Newman, R., Trebar, M., Catarinucci, L., \& Melcon, A. A. (2014). RFID-Based Traceability Along the Food-Production Chain. Ieee Antennas and Propagation Magazine, 56(2), 196-207.

Dabbene, F., Gay, P., \& Tortia, C. (2014). Traceability issues in food supply chain management: A review. Biosystems Engineering, 120, 65-80. doi:10.1016/j.biosystemseng.2013.09.006

Dandage, K., Badia-Melis, R., \& Ruiz-Garcia, L. (2017). Indian perspective in food traceability: A review. Food Control, 71, 217-227. doi:10.1016/j.foodcont.2016.07.005

Denso ADC. (2011). QR Code Essentials. Retrieved from http://www.nacs.org/LinkClick.aspx?fileticket=D1FpVAvvJuo\%3D\&tabid=1426\& $\underline{\operatorname{mid}=4802}$

EU. (2002). Regulation (EC) No 178/2002 of the European parliament and of the council. Official Journal of the European Communities.

Fuertes, G., Soto, I., Carrasco, R., Vargas, M., Sabattin, J., \& Lagos, C. (2016). Intelligent Packaging Systems: Sensors and Nanosensors to Monitor Food Quality and Safety. Journal of Sensors, 8. doi:10.1155/2016/4046061

Gessner, G. H., Volonino, L., \& Fish, L. A. (2007). One-up, one-back ERM in the food supply chain. Information Systems Management, 24(3), 213-222. doi:10.1080/10580530701404561

Giannoglou, M., Touli, A., Platakou, E., Tsironi, T., \& Taoukis, P. S. (2014). Predictive modeling and selection of TTI smart labels for monitoring the quality and shelf-life of frozen seafood. Innovative Food Science \& Emerging Technologies, 26, 294301. doi:10.1016/j.ifset.2014.10.008

Hafliðason, T., Olafsdottir, G., Bogason, S., \& Stefansson, G. (2012). Criteria for temperature alerts in cod supply chains. International Journal of Physical Distribution \& Logistics Management, 42(4), 355-371. doi:10.1108/09600031211231335

Handfield, R. B., \& Melnyk, S. A. (1998). The scientific theory-building process: a primer using the case of TQM. Journal of Operations Management, 16(4), 321-339. doi:http://doi.org/10.1016/S0272-6963(98)00017-5 
Heising, J. K., Dekker, M., Bartels, P. V., \& Van Boekel, M. (2014). Monitoring the Quality of Perishable Foods: Opportunities for Intelligent Packaging. Critical Reviews in Food Science and Nutrition, 54(5), 645-654.

doi:10.1080/10408398.2011.600477

Hickey, C., \& Bhatt, T. (2013). Proceedings of the November 2011 Traceability Research Summit This report is the third in a series on Traceability Summits sponsored by IFT beginning in July 2011. Journal of Food Science, 78, B15-B20. doi:10.1111/1750-3841.12042

Kelepouris, T., Pramatari, K., \& Doukidis, G. (2007). RFID-enabled traceability in the food supply chain. Industrial Management \& Data Systems, 107(1-2), 183-200. doi:10.1108/02635570710723804

Khan, M. A., Sharma, M., \& Prabhu, H. (2009). A survey of RFID tags. International Journal of Recent Trends in Engineering, 1(4).

Kumar, P., Reinitz, H. W., Simunovic, J., Sandeep, K. P., \& Franzon, P. D. (2009). Overview of RFID Technology and Its Applications in the Food Industry. Journal of Food Science, 74(8), R101-R106. doi:10.1111/j.1750-3841.2009.01323.x

Kumari, L., Narsaiah, K., Grewal, M. K., \& Anurag, R. K. (2015). Application of RFID in agri-food sector. Trends in Food Science \& Technology, 43(2), 144-161. doi:10.1016/j.tifs.2015.02.005

Laniel, M., Emond, J. P., \& Altunbas, A. E. (2011). Effects of antenna position on readability of RFID tags in a refrigerated sea container of frozen bread at 433 and 915 MHz. Transportation Research Part C-Emerging Technologies, 19(6), 10711077. doi:10.1016/j.trc.2011.06.008

Lavelli, V. (2013). High-warranty traceability system in the poultry meat supply chain: A medium-sized enterprise case study. Food Control, 33(1), 148-156.

doi:10.1016/j.foodcont.2013.02.022

Luo, H., Zhu, M. J., Ye, S. G., Hou, H. P., Chen, Y., \& Bulysheva, L. (2016). An intelligent tracking system based on internet of things for the cold chain. Internet Research, 26(2), 435-445. doi:10.1108/IntR-11-2014-0294

Mai, N., Bogason, S. G., Arason, S., Arnason, S. V., \& Matthiasson, T. G. (2010). Benefits of traceability in fish supply chains - case studies. British Food Journal, 112(8-9), 976-1002. doi:10.1108/00070701011074354

Mai, N. T. T., Margeirsson, S., Stefansson, G., \& Arason, S. (2010). Evaluation of a seafood firm traceability system based on process mapping information: More efficient use of recorded data. Journal of Food Agriculture \& Environment, 8(2), 51-59.

Mgonja, J. T., Luning, P., \& Van der Vorst, J. (2013). Diagnostic model for assessing traceability system performance in fish processing plants. Journal of Food Engineering, 118(2), 188-197. doi:10.1016/j.jfoodeng.2013.04.009 
Mohebi, E., \& Marquez, L. (2015). Intelligent packaging in meat industry: An overview of existing solutions. Journal of Food Science and Technology-Mysore, 52(7), 39473964. doi:10.1007/s13197-014-1588-z

Monnit. (2017). MONNIT WIRELESS TEMPERATURE SENSOR - COMMERCIAL COIN CELL POWERED. Retrieved from http://www.monnit.com/Products/Wireless-Sensors/Coin-Cell/WirelessTemperature-Sensors

NovaVision. (2017). Security Hologram Labels and Stickers. Retrieved from https://www.novavisioninc.com/pages/prd_hologram_holograms.html

Olsen, P., \& Borit, M. (2013). How to define traceability. Trends in Food Science \& Technology, 29(2), 142-150. doi:10.1016/j.tifs.2012.10.003

OMAK. (2017). PrinLab - A development laboratory for printable electronics. Retrieved from http://www.oamk.fi/hankkeet/prinlab/

Parreno-Marchante, A., Alvarez-Melcon, A., Trebar, M., \& Filippin, P. (2014). Advanced traceability system in aquaculture supply chain. Journal of Food Engineering, 122, 99-109. doi:10.1016/j.jfoodeng.2013.09.007

Phase IV Engineering INC. (2016). Temperature Sensor, Credit Card Size, RFID BatteryFree Passive UHF EPC. Retrieved from http://www.phaseivengr.com/product/temperature-sensor-credit-card-size-rfidbattery-free-passive-uhf-epc/

Pizzuti, T., \& Mirabelli, G. (2015). The Global Track\&Trace System for food: General framework and functioning principles. Journal of Food Engineering, 159, 16-35. doi:10.1016/j.jfoodeng.2015.03.001

Red Cell Innovation. (2017). Cold Chain Tags. Retrieved from http://two-redcells.com/products/rfid/tags/cold\%20chain

RFMicron. (2017). RFM3200 Wireless Flexible Temperature Sensor. Retrieved from http://rfmicron.com/rfm3200-wireless-flexible-temperature-sensor/\#

Ringsberg, H. (2014). Perspectives on food traceability: a systematic literature review. Supply Chain Management-an International Journal, 19(5-6), 558-576. doi:10.1108/scm-01-2014-0026

Ringsberg, H. A. (2015). Implementation of global traceability standards: incentives and opportunities. British Food Journal, 117(7), 1826-1842. doi:10.1108/bfj-10-20140353

Ringsberg, H. A., \& Mirzabeiki, V. (2014). Effects on logistic operations from RFID- and EPCIS-enabled traceability. British Food Journal, 116(1), 104-124. doi:10.1108/bfj-03-2012-0055 
Ruiz-Garcia, L., Barreiro, P., Robla, J. I., \& Lunadei, L. (2010). Testing ZigBee Motes for Monitoring Refrigerated Vegetable Transportation under Real Conditions. Sensors, 10(5), 4968-4982. doi:10.3390/s100504968

Ruiz-Garcia, L., \& Lunadei, L. (2011). The role of RFID in agriculture: Applications, limitations and challenges. Computers and Electronics in Agriculture, 79(1), 42-50. doi:10.1016/j.compag.2011.08.010

Ruiz-Garcia, L., Lunadei, L., Barreiro, P., \& Robla, J. I. (2009). A Review of Wireless Sensor Technologies and Applications in Agriculture and Food Industry: State of the Art and Current Trends. Sensors, 9(6), 4728-4750. doi:10.3390/s90604728

Sharma, D., \& Panwar, K. (2014). Radio Frequency Identificaion (RFID). International Journal of Research, , 1(9), 5.

Shore, J. (2014). These 10 Peter Drucker Quotes May Change Your World. Make More Happen. Retrieved from https://www.entrepreneur.com/article/237484

Storoy, J., Thakur, M., \& Olsen, P. (2013). The Trace Food Framework - Principles and guidelines for implementing traceability in food value chains. Journal of Food Engineering, 115(1), 41-48. doi:10.1016/j.jfoodeng.2012.09.018

Stuart, I., McCutcheon, D., Handfield, R., McLachlin, R., \& Samson, D. (2002). Effective case research in operations management: a process perspective. Journal of Operations Management, 20(5), 419-433. doi:10.1016/s0272-6963(02)00022-0

Texim-Europe. (2017). COIN-T-ELA 433MHz Active RFID Tag With Internal Temperature Sensor. Retrieved from https://www.teximeurope.com/product/COIN-T-ELA\#

TGoldkamp. (2017). 3M ${ }^{\mathrm{TM}}$ MonitorMark ${ }^{\mathrm{TM}}$ Time Temperature Indicator 9860D $\left(10^{\circ} \mathrm{C} / 50^{\circ} \mathrm{F}\right) 1 \mathrm{Week}$. Retrieved from http://www.tgoldkamp.com/3mmonitormark-time-temperature-indicator-9860d-10-c-50-f-1-week.html

The Associated Press. (2013). Tesco sales fall after horsemeat scandal. Retrieved from http://www.sandiegouniontribune.com/sdut-tesco-sales-fall-after-horsemeatscandal-2013jun05-story.html

TIP TEMPerature Products. (2017a). Monitor Mark Dual Temperature. Retrieved from http://www.tiptemp.com/Products/Rising-Time-Temperature-IndicatingLabels/THGSEN009-Temperature-Label-Monitor-Mark-Model-9861A-50F-10C93F-34C-2-weeks.html

TIP TEMPerature Products. (2017b). WarmMark Indicator $5^{\circ} \mathrm{C} / 41^{\circ} \mathrm{F}$. Retrieved from http://www.tiptemp.com/Products/Rising-Time-Temperature-IndicatingLabels/WMSSEN003.html

Trebar, M., Lotric, M., Fonda, I., Pletersek, A., \& Kovacic, K. (2013). RFID Data Loggers in Fish Supply Chain Traceability. International Journal of Antennas and Propagation, 9. doi:10.1155/2013/875973 
U.S. Food and Drug Administration. (2002). The Bioterrorism Act of 2002. Retrieved from https://www.fda.gov/regulatoryinformation/lawsenforcedbyfda/ucm148797.htm

U.S. Food and Drug Administration. (2011). The Food Safety Modernization Act (FSMA). 111th Congress Public Law 353. Retrieved from https://www.gpo.gov/fdsys/pkg/PLAW-111pub1353/pdf/PLAW-111publ353.pdf

Wang, J. Y., Wang, H., He, J., Li, L. L., Shen, M. G., Tan, X., . . Zheng, L. R. (2015). Wireless sensor network for real-time perishable food supply chain management. Computers and Electronics in Agriculture, 110, 196-207. doi:10.1016/j.compag.2014.11.009

Xiao, X. Q., He, Q. L., Fu, Z. T., Xu, M., \& Zhang, X. S. (2016). Applying CS and WSN methods for improving efficiency of frozen and chilled aquatic products monitoring system in cold chain logistics. Food Control, 60, 656-666. doi:10.1016/j.foodcont.2015.09.012

Zhang, J. R., \& Bhatt, T. (2014). A Guidance Document on the Best Practices in Food Traceability. Comprehensive Reviews in Food Science and Food Safety, 13(5), 1074-1103. doi:10.1111/1541-4337.12103

Zou, Z., Chen, Q., Uysal, I., \& Zheng, L. R. (2014). Radio frequency identification enabled wireless sensing for intelligent food logistics. Philosophical Transactions of the Royal Society a-Mathematical Physical and Engineering Sciences, 372(2017), 16. doi:10.1098/rsta.2013.0313 


\section{Appendix}

Table 0.1 Question list for field trip to Oulu

\begin{tabular}{|c|c|c|c|}
\hline Function & Comment & $\begin{array}{c}\text { For the } \\
\text { framework? }\end{array}$ & Answers \\
\hline Range & $\begin{array}{l}\text { How long does it have to be? } \\
\text { What is enough? }\end{array}$ & Over $\mathrm{X}$ & $\begin{array}{l}\text { As long as the largest } \\
\text { containers are (ca } 20 \mathrm{~m} \text { ) }\end{array}$ \\
\hline Size & $\begin{array}{l}\text { Can't be too big, we want it to } \\
\text { be printable in the future }\end{array}$ & Under X & $\begin{array}{l}\text { Small } \\
70 \times 30 \times 0,125 \mathrm{~mm}\end{array}$ \\
\hline Frequency & $\begin{array}{l}\text { How do they choose it? What } \\
\text { about jamming if } 2.4 \mathrm{GHz} \text { ? } \\
\text { Standards between continents }\end{array}$ & Range $X$ & $\begin{array}{l}\text { It is an open frequency and } \\
\text { standardized for the } \\
\text { technology being used }\end{array}$ \\
\hline Battery life & $\begin{array}{l}\text { Does it get to } 30 \text { days? (cold } \\
\text { chain) }\end{array}$ & Over 30 days & The aim is 96 hours \\
\hline Security & $\begin{array}{l}\text { Is there any? Is it good? } \\
\text { Encryption? }\end{array}$ & & $\begin{array}{l}\text { The users must log into a } \\
\text { secure site to be able to see } \\
\text { the data }\end{array}$ \\
\hline Protocol / Standard & $\begin{array}{l}\text { How did they choose e.g. Digi } \\
\text { XBee and Bluetooth? Why that } \\
\text { one and not something else? }\end{array}$ & & $\begin{array}{l}\text { They are considering a lot of } \\
\text { different technology since it } \\
\text { is easy to implement and it } \\
\text { takes time to do it from } \\
\text { scratch }\end{array}$ \\
\hline Cost & $\begin{array}{l}\text { We want it in the passive tag } \\
\text { range / barcode that is around } \\
10 \text { cent }\end{array}$ & Under X & $\begin{array}{l}\text { It is too expensive right now } \\
\text { but first they are going to } \\
\text { find a solution and then } \\
\text { hopefully decrease the cost } \\
\text { ( } 200 \text { euros) }\end{array}$ \\
\hline $\begin{array}{l}\text { Real-time } \\
\text { communication }\end{array}$ & $\begin{array}{l}\text { Can it communicate in real } \\
\text { time? }\end{array}$ & $\mathrm{Y} / \mathrm{N}$ & $\begin{array}{l}\text { Yes, through the router } \\
\text { system it will be able to send } \\
\text { real time data }\end{array}$ \\
\hline Memory & $\begin{array}{l}\text { Can it store enough data } \\
\text { points? }\end{array}$ & Over X & $\begin{array}{l}\text { The data will be stored on } \\
\text { the router and online in the } \\
\text { cloud, tag => send - sleep - } \\
\text { send - sleep }\end{array}$ \\
\hline $\begin{array}{l}\text { Environmental } \\
\text { conditions }\end{array}$ & $\begin{array}{l}\text { Can it withstand the cold, } \\
\text { humidity, impacts... }\end{array}$ & $\mathrm{Y} / \mathrm{N}$ & $\begin{array}{l}\text { Will print an insulating layer } \\
\text { on the printable tag to } \\
\text { protect it from e.g. } \\
\text { temperature }(-20 /+35) \text {, salt, } \\
\text { impact, repeatable bending } \\
\text { humidity... }\end{array}$ \\
\hline $\begin{array}{l}\text { Size of network if } \\
\text { WSN }\end{array}$ & $\begin{array}{l}\text { Can it handle many items in } \\
\text { the network? }\end{array}$ & $\mathrm{Y} / \mathrm{N}$ & $\begin{array}{l}\text { The ZigBee can handle up to } \\
200 \text {, but it must be tested } \\
\text { more, and Thread can have } \\
250+\end{array}$ \\
\hline Alerts & $\begin{array}{l}\text { Does it send alerts e.g. if } \\
\text { temperature is too high? }\end{array}$ & $\mathrm{Y} / \mathrm{N}$ & $\begin{array}{l}\text { Will send a text message } \\
\text { when the temperature goes } \\
\text { out of range, right now you } \\
\text { can see it online on the } \\
\text { webpage / app }\end{array}$ \\
\hline
\end{tabular}




\begin{tabular}{|c|c|c|c|}
\hline $\begin{array}{l}\text { Mesh network if } \\
\text { WSN }\end{array}$ & Was that needed? & $\mathrm{Y} / \mathrm{N}$ & $\begin{array}{l}\text { By having a mesh network, it } \\
\text { can send data even if one } \\
\text { sensor is bad, yes needed }\end{array}$ \\
\hline $\begin{array}{l}\text { Message / Data } \\
\text { frequency }\end{array}$ & How often will it send RT data? & Interval & $\begin{array}{l}\text { Right now, it sends every } \\
\text { minute but it can be } \\
\text { changed, based on the user }\end{array}$ \\
\hline Interoperability & $\begin{array}{l}\text { Is that important for us? Does } \\
\text { it communicate with other } \\
\text { devices? }\end{array}$ & $\mathrm{Y} / \mathrm{N}$ & $\begin{array}{l}\text { It communicates with the } \\
\text { router }\end{array}$ \\
\hline Transportation & $\begin{array}{l}\text { Does it function for all kinds of } \\
\text { transportation, on sea and } \\
\text { land? }\end{array}$ & $\mathrm{Y} / \mathrm{N}$ & $\begin{array}{l}\text { Right now, they seem to be } \\
\text { focusing on road } \\
\text { transportation but hopefully } \\
\text { on sea will also be possible, } \\
\text { needs testing, not air too } \\
\text { many regulations }\end{array}$ \\
\hline $\begin{array}{l}\text { Loading and } \\
\text { unloading }\end{array}$ & Will that be possible? & $\mathrm{Y} / \mathrm{N}$ & $\begin{array}{l}\text { Router system will be in } \\
\text { warehouses and } \\
\text { transportation }\end{array}$ \\
\hline Temperature range & What is it? & Range & -1 to $10^{\circ} \mathrm{C}+-0.5$ \\
\hline Printable & Will it be? & $\mathrm{Y} / \mathrm{N}$ & $\begin{array}{l}\text { The aim is to have it } \\
\text { printable and flexible so not } \\
\text { rigid }\end{array}$ \\
\hline Future possibilities & $\begin{array}{l}\text { Is there any new technology } \\
\text { like the Bluetooth } 5 \text { that could } \\
\text { improve the RFID tag? }\end{array}$ & - & $\begin{array}{l}\text { Are testing a lot of different } \\
\text { technologies }\end{array}$ \\
\hline
\end{tabular}

